Int. J. Dev. Biol. 58: 247-259 (2014)

doi: $10.1387 / \mathrm{ijdb} .140083 \mathrm{~ms}$

\title{
Adaptive mechanisms controlling uterine spiral artery remodeling during the establishment of pregnancy
}

\author{
MICHAEL J. SOARES*, DAMAYANTI CHAKRABORTY, KAIYU KUBOTA, \\ STEPHEN J. RENAUD and M.A. KARIM RUMI \\ Institute for Reproductive Health and Regenerative Medicine, Department of Pathology and Laboratory Medicine, \\ University of Kansas Medical Center, Kansas City, Kansas, USA
}

\begin{abstract}
Implantation of the embryo into the uterus triggers the initiation of hemochorial placentation. The hemochorial placenta facilitates the acquisition of maternal resources required for embryo/fetal growth. Uterine spiral arteries form the nutrient supply line for the placenta and fetus. This vascular conduit undergoes gestation stage-specific remodeling directed by maternal natural killer cells and embryo-derived invasive trophoblast lineages. The placentation site, including remodeling of the uterine spiral arteries, is shaped by environmental challenges. In this review, we discuss the cellular participants controlling pregnancy-dependent uterine spiral artery remodeling and mechanisms responsible for their development and function.
\end{abstract}

KEYWORDS: hemochorial placentation, naturalkiller cell, trophoblast, PI3K/AKT, FOSL1, hypoxia, NOTCH, STOX1

\section{Introduction}

The embryo implants into the uterus to gain access to maternal nutrients. Delivery of nutrients is facilitated by the placenta, which develops in association with the embryo/fetus. Trophoblast cells are the functional units of the placenta and key contributors to establishing the maternal-fetal interface. Hemochorial is the categorization of placentation displaying the closest connections between maternal and fetal tissues (Amoroso 1959; Mossman 1987; Wooding and Burton 2008). Maternal blood directly bathes trophoblast, which requires restructuring of the uterine spiral arterial tree. Distal segments of the uterine spiral arterial tree are targeted and structurally modified to create conduits with altered vasoregulation properties, maximizing the flow of maternal resources to the placenta (Osol and Mandala 2009; Leonard et al., 2013; Osol and Moore 2014). This represents an orchestrated process involving the activities of specialized cell types derived from trophectoderm (outer layer of the blastocyst-stage embryo) and the modulatory influences of cells situated within the uterine stromal compartment (Pijnenborg et al., 2006; Wallace et al., 2012). The extent of pregnancy-dependent uterine spiral artery remodeling differs among species (Amoroso 1959; Mossman 1987; Wooding and Burton 2008) and aberrations in uterine vascular modifications are associated with pregnancy-related diseases (Pijnenborg et al., 2006; Wallace et al., 2012).
In this review, we discuss the cellular participants controlling pregnancy-dependent uterine spiral artery remodeling and mechanisms responsible for their development and function.

\section{Uterine spiral artery remodeling}

Uterine spiral arteries are the conduits for delivering maternal nutrients to the fetus. These blood vessels undergo restructuring during the establishment of pregnancy (Pijnenborg et al., 2006; Osol and Mandala 2009; Harris 2010). The maternal uterine spiral arteries undergoes fundamental changes of their cellular (endothelial and smooth muscle cell) and extracellular constituents, including hyperplasia, hypertrophy, apoptosis, dedifferentiation, migration, and extracellular matrix remodeling (Osol and Mandala 2009; Harris 2011). We focus on two key architects of uterine spiral artery remodeling: maternal natural killer (NK) cells and invasive trophoblast cells of extraembryonic origin (Smith et al., 2009; Harris 2011; Wallace et al., 2012). Other cell types, such as maternal macrophages, also contribute to the remodeling process (Smith et al., 2009). There is a temporal dependence to NK cell and trophoblast contributions during pregnancy with NK cells arriving and acting first followed by invasive trophoblast

Abbreviations used in this paper: NK, natural killer cell; TS, trophoblast stem cell.

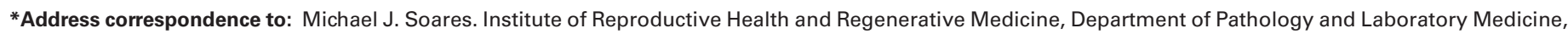
University of Kansas Medical Center, MS3050, 3901 Rainbow Boulevard, Kansas City, KS, USA 66160. Tel: +1-(913)-588-5691. Fax +1-(913)-588-8287.

E-mail: msoares@kumc.edu
}

Final, author-corrected PDF published online: 8 July 2014.

ISSN: Online 1696-3547, Print 0214-6282 
cells. Each cell type exhibits similarities and differences in their tasks. Both NK cells and trophoblast cells target the extracellular matrix and smooth muscle cells surrounding the spiral arteries leading to an alteration of vasoregulation and the facilitation of nutrient delivery (Wallace et al., 2012). Trophoblast cells go even further and supplant the endothelium of distal arterial segments. Subsequently, they assume a phenotype resembling the endothelium termed pseudo-vascularization (Damsky and Fisher 1998; Rai and Cross 2014). The actions and effectiveness of these specialized cell populations are guided through signals impinging on the intrauterine environment. They react and adapt to appropriately direct formation of the maternal-fetal interface, balancing the needs of the mother and fetus. Aberrations in NK cell and/ or invasive trophoblast cell performance lead to disruptions in nutrient delivery to the placenta and subsequently to the embryo.

\section{Models for studying mechanisms controlling uterine spiral artery remodeling}

Control systems regulating any aspect of the vascular network can be complex and difficult to analyze. Uterine spiral artery remodeling is no exception. Human placentation exhibits extensive uterine spiral artery remodeling guided through the actions of NK cells and invasive trophoblast. Effective dissection of mechanisms controlling uterine spiral artery remodeling requires a combined in vivo and in vitro effort, which presents limitations for investigations of the in vivo pregnant human intrauterine environment. There is an assortment of mammalian species adapted to laboratory research that possess hemochorial placentation and could potentially be used to model uterine spiral artery remodeling; however, all are not suitable. Although, hemochorial placentation exhibits elements of conservation across mammalian species, it also shows striking differences, including a dearth of trophoblast involvement in uterine spiral artery remodeling in some species, notably the mouse (Adamson et al., 2002; Ain et al., 2003). In contrast, placentation in other common laboratory species, including the rat, hamster, and guinea pig possess deep trophoblast invasion not unlike that seen in human placentation (Pijnenborg and Vercruysse 2010). The rat is an effective model for examining regulatory roles of both NK cells and invasive trophoblast in uterine spiral artery remodeling (Soares et al., 2012; Fig. 1). The rat is especially attractive because excellent in vitro and in vivo approaches have been established for dissecting regulatory pathways controlling placentation. Trophoblast stem (TS) cells can be isolated from early embryos and readily propagated and manipulated for experimentation on invasive trophoblast lineage differentiation (Asanoma et al., 2011; Chakraborty et al., 2011; Kent et al., 2011; Konno et al., 2011). The size of the rat presents advantages for surgical preparations and repeated tissue sampling, and the rat can be genetically modified using newly developed genome editing strategies (Jacob et al., 2010; Rumi et al., 2014). These approaches coupled to complementary experimentation with ex vivo human tissues obtained from normal and diseased placentation sites (Aplin 2006; Hunkapiller and Fisher 2008; Hazan et al., 2010; Robson et al., 2012), a collection of immortalized human extravillous trophoblast cell lines (HTR-8/ SVneo, SGHPL-4/5, Swan 71; Graham et al., 1993; Whitley 2006; Straszewski-Chavez et al., 2009), and BMP4-treated human embryonic or induced pluripotent stem cells (Xu et al., 2002; Ezashi et al., 2011; Amita et al., 2013; Li et al., 2013) provide a robust toolset for dissecting conserved mechanisms regulating the maternal-fetal interface.
Fig. 1. Hemochorial placentation. Schematic diagram showing homologous structures within human and rat hemochorial placentation sites. In the human, trophoblast cells destined for the maternal compartment are referred to as extravillous trophoblast cells, whereas in the rat these cells are referred to as invasive trophoblast cells. Invasive trophoblast cells are specialized into interstitial and endovascular subtypes. Collectively, invasive trophoblast cells and natural killer cells direct uterine spiral artery restructuring. Adapted from Soares et al., 2012.

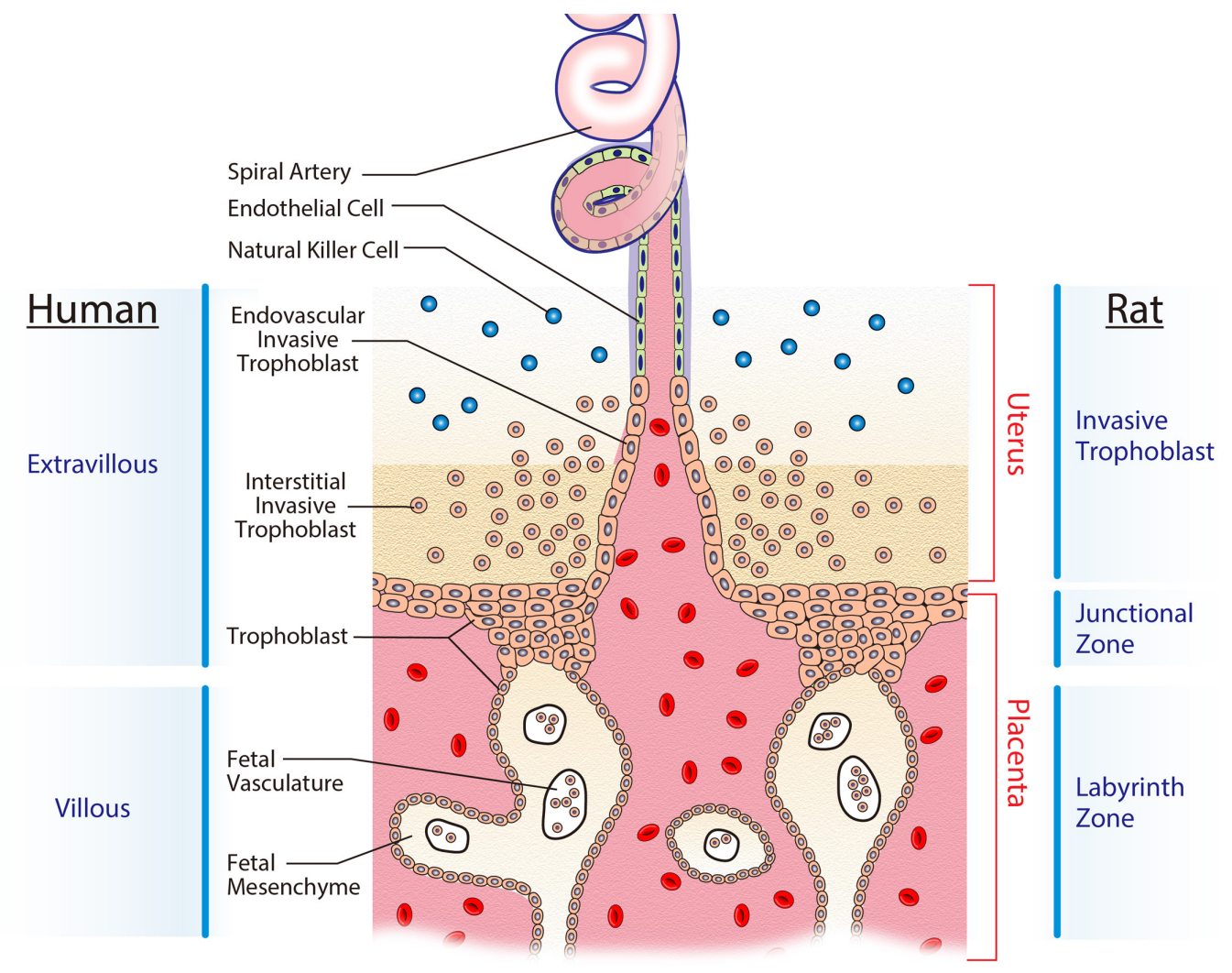




\section{Natural killer (NK) cells}

NK cells are constituents of the innate immune system possessing unique trafficking characteristics during pregnancy. Unlike other immune cell lineages, NK cells accumulate at the implantation site. These NK cells possess a unique phenotype and are distinct from circulating NK cells (Koopman et al., 2003; Cerdeira et al., 2013). They are embedded in the decidua and establish conspicuous relationships with uterine spiral arteries and invasive trophoblast cells, a process conserved among rodents and primates (Chakraborty et al., 2011; Zhang et al., 2011; Dambaeva et al., 2012). NK cell deficient animal models have been used to demonstrate the involvement of NK cells in uterine spiral artery remodeling (Guimond et al., 1997; Barber and Pollard 2003; Chakraborty et al., 2011). This assessment has been supported by co-culture experiments involving NK cells and uterine spiral artery segments (Robson et al., 2012). NK cells contribute to pregnancy-dependent restructuring of the uterine spiral arteries, especially loss of tunica media integrity, which facilitates fetal nutrient delivery. Infiltration, differentiation, and maintenance of NK cells within the uterus during the establishment of pregnancy are influenced by interleukin 15 , interleukin 11, Hoxa-10, transforming growth factor- $\beta$ (TGFB), bone morphogenetic protein (BMP), and adrenomedullin signaling pathways (Barber and Pollard 2003; Ain et al., 2004; Rahman et al., 2006; Keskin et al., 2007; Li et al., 2013; Nagashima et al., 2013). NK cell effects on uterine spiral arteries may be mediated by interferon $\gamma$ (Ashkar and Croy, 2001), nitric oxide (Hunt et al., 1997), and an assortment of angiogenic growth factors and extracellular matrix modifying enzymes (Li et al., 2001; Wang et al., 2000, 2003; Hanna et al., 2006; Lash et al., 2006b; Kopcow and Karumanchi 2007; Wallace et al., 2012).

NK cells have also been implicated in the regulation of trophoblast cell invasion into the uterus and trophoblast cell interactions with uterine spiral arteries. A range of direct actions of NK cells on trophoblast cells has been postulated based primarily on in vitro analyses. The outcomes of these experiments are not entirely consistent and are likely influenced by the gestational age of the specimens and culture conditions. Some studies provide evidence for NK cell promotion of trophoblast migration and invasiveness (Hanna etal., 2006; Lash et al., 2010; Wallace et al., 2013), whereas other reports show that NK cells and their secretory products inhibit these vital functions (Ain et al., 2003; Hu et al., 2006; Lash et al., 2006a; Eastabrook et al., 2008). Furthermore some researchers have advocated for the importance of physical interactions between NKcells and invasive trophoblast cells. Specific patterns of polymorphic trophoblast cell surface ligands consisting of histocompatibility antigen isoforms and their cognate polymorphic NK cell receptor isoforms can define successful versus compromised pregnancies (Hiby et al., 2004; Parham and Moffett 2013; Xiong et al., 2013; Kieckbusch et al., 2014). These NK cell receptor-trophoblast cell histocompatibility antigen interactions may be best developed in primates (Parham and Moffett 2013). Direct signaling between NK cells and trophoblast cells is intriguing; however, the indirect actions of NK cells on trophoblast development via their effects on the vasculature may be as compelling.

Pivotal insights into the roles of NK cells in the regulation of hemochorial placentation were achieved using an in vivo rat model (Chakraborty et al., 2011). An immunodepletion strategy was employed to remove uterine NK cells during the establishment of the hemochorial placenta. The resulting phenotype confirmed a role for NK cells in the development and restructuring of uterine spiral arteries and unexpected functions in modulating the invasive trophoblast lineage. Surprisingly, trophoblast-directed uterine spiral artery remodeling was accelerated and much more pronounced in the absence of NK cells. The presence of NK cells also influenced the trophoblast pseudovascular phenotype. Based on these observations it was proposed that any actions of NK cells in promoting trophoblast endovascular invasion must be subtle and secondary to an overall restraining function (Chakraborty et al., 2011). Furthermore, the NK cell inhibitory action was viewed as indirect through NK cell regulation of uterine spiral artery development. Depletion of NK cells limited uterine mesometrial vascular development, lowering oxygen tension at the placentation site, and triggering trophoblast lineage decisions favoring differentiation of the invasive trophoblast lineage. Thus NK cell modulation of oxygen delivery is viewed as a key signal impacting trophoblast invasiveness and trophoblast-directed uterine spiral artery remodeling. These insights required an in vivo test using the rat, a species with deep trophoblast invasion.

Overview. NK cells have two key higher order functions regarding hemochorial placentation. They collectively act as a pacemaker, determining the timing of key developmental events and they fine-tune placental morphogenesis, defining the allocation of trophoblast lineages and thus the structure/function features of the placenta. The operative NK cell functions are to delay and restrict the invasive trophoblast program. In performing these tasks they effectively protect the mother and prevent precocious and excessive trophoblast invasion and restructuring of the uterine spiral arteries.

\section{Trophoblast lineage development}

Placentation is characterized by temporally and spatially relevant differentiation of trophoblast cells. The first cellular specification event during development occurs as totipotent cells of the embryo are allocated to an outer position (trophectoderm) versus an inner position (inner cell mass; Cockburn and Rossant 2010). Trophectoderm is destined for expansion as a multi-potential trophoblast stem (TS) cell population and further differentiation into specialized trophoblast cell types (e.g. invasive trophoblast, syncytiotrophoblast, etc), whereas cells of the inner cell mass retain a broader developmental potential, including the ability to form embryonic and extraembryonic structures. Some regulatory factors controlling trophoblast lineage determination, expansion, and differentiation have been discerned (Roberts and Fisher 2011; Pfeffer and Pearton 2012).

Extracellular signal control. Fibroblast growth factor (FGF)- and BMP-mediated signaling pathways are key regulators of the trophoblast lineage. The FGF4-FGFR2 signaling pathway promotes self-renewal in rodent TS cells (Tanaka et al., 1998; Abell et al., 2009; Murohashi etal., 2010; Asanoma et al., 2011). These cells can be maintained in a proliferative stem state or they can be induced to differentiate into specialized trophoblast lineages (Tanaka et al., 1998; Asanoma et al., 2011). A cocktail containing FGF4 and either TGFB or activin is sufficient to maintain TS cells ex vivo in a proliferative and undifferentiated state (Erlebacher et al., 2004; Kubaczka et al., 2014). An in vivo corollary to the TS cell has been identified in both rodent and human placentation sites (Rielland et al., 2008; Hemberger et al., 2010; Roberts and Fisher 2011; Pfef- 
fer and Pearton 2012). However, the presumptive human TS cell population has not been successfully propagated ex vivo. There have been some attempts at isolating and culturing TS/trophoblast progenitor cell populations (Genbacev et al., 2011; Takao et al., 2011). These cells self renew and possess some capacity to differentiate into specialized trophoblast cell types; however, they exhibit a very different gene expression profile than do rodent TS cells or the putative TS cells identified in the human placenta (Hemberger et al., 2010). BMP4 is a downstream target of the FGF4-FGFR2 pathway in rodent TS cells (Murohashi et al., 2010) and is also an inducer of the trophoblast lineage when presented to pluripotent stem cells (Xu et al., 2002; Ezashi et al., 2012; Amita et al., 2013; Li et al., 2013). Following BMP4 treatment, pluripotent stem cells exhibit features of specialized differentiated trophoblast lineages. Presumably a multipotent TS cell population arises as the pluripotent stem cells commit to the trophoblast lineage; however, these cells have not yet been captured and propagated ex vivo. Expansion of such a cell population may require supplementation with special TS cell sustaining factors that are yet to be identified. The power of this pluripotent stem cell system for studying development of the trophoblast lineage is twofold: i) trophoblast development of the pluripotent stem cells is activated by BMP4, a known physiological regulator of trophoblast lineage determination (Hayashi et al., 2010; Amita et al., 2013; Home et al., 2013; Li et al., 2013) and ii) the model system is a window into the development of human trophoblast (Ezashi et al., 2012).

Transcriptional/epigenetic control. During trophoblast lineage determination, key factors sustaining the totipotent state are repressed and/or downregulated, while other key factors supporting the trophoblast lineage are activated and/or upregulated. These factors include transcription factors, histone modifiers, and chromatin organizers. POU5F1 (also called OCT4) is an essential transcription factor promoting totipotency and inhibiting trophoblast lineage development, whereas transcription factors such as TEAD4, CDX2, and EOMES are critical for development of the trophoblast lineage (Roberts and Fisher 2011; Pfeffer and Pearton 2012). Ectopic expression of any of these three transcription factors can convert pluripotent mouse embryonic stem cells into TS cells (Niwa et al., 2005; Tolkunova etal., 2006; Nishioka et al., 2009). TEAD4 is an upstream regulator of CDX2 and CDX2 is an upstream regulator of EOMES. SOX2, ESRRB, and TCFAP2C are essential for TS cell self-renewal

Fig. 2. Overview of the developmental progression from a totipotent stem cell to a multipotent trophoblast stem (TS) cell to a specialized differentiated trophoblast cell. Each step along the developmental progression is controlled by positive and negative modulatory factors. These factors can be characterized as transcription factors, histone modifiers, and chromatin organizers (lists are provided in boxes below each cell type). See text for additional information.
(Adachi et al., 2013). These transcription factors and others, including GATA3, ELF5, and ETS2 contribute to development of the trophoblast lineage but their positions in the gene regulatory network are not yet precisely defined (Tremblay et al., 2001; Wen et al., 2007; Ng et al., 2008; Home et al., 2009, 2012; Keramari et al., 2010; Kidder and Palmer 2010; Kuckenberg et al., 2010; Ralston et al., 2010; Adachi et al., 2013; Choi et al., 2013). The actions of these transcription factors are presumably mediated through the delivery of enzymatic machinery that post-translationally modifies histones creating chromatin states that are more favorable or less favorable for transcription. Modulation of histone post-translational modifications has been implicated in the regulation of TS cell stemness and differentiation (Yeap et al., 2009; Yuan et al., 2009; Alder et al., 2010; Rugg-Gunn et al., 2010; Santos et al., 2010; Abell et al., 2011; Chuong et al., 2013; Saha et al., 2013). Collectively, each of these transcription factor and histone modifier activities is coordinated by a higher order of regulation controlled by chromatin organizers. SATB1 and SATB2 are prototypical genome organizers and have been implicated in controlling the TS cell stem state (Asanoma et al., 2012). Trophoblast lineage specific differentiation requires the downregulation of factors that maintain the TS cell stem state and activation of regulatory factors that promote lineage-specific differentiation. For example, CDX2, EOMES, SOX2, ID1/2, ESRRB, ELF5, and SATB1/2 sustain the TS cell stem state and are downregulated during differentiation (Tanaka et al., 1998; Janatpour et al., 2000; Ralston et al., 2010; Asanoma et al., 2011; Adachi et al., 2013), whereas transcription factors such as GCM1, GATA2, ASCL2, FOSL1, JUNB, BHLHE40, and OVOL2 are activated and promote differentiation into mature sub-lineages (Tanaka et al., 1998; Janatpour et al., 1999; SchorppKistner et al., 1999; Schreiber et al., 2000; Hughes et al., 2004; Ray et al., 2009; Asanoma et al., 2011; Kent et al., 2011; Ueno et al., 2013; Renaud et al., 2014; Zhu et al., 2014). A schematic of the progression from a totipotent stem cell to a multipotent TS cell to a specialized differentiated trophoblast cell is shown in Fig. 2. In summary, transcription factors, histone modifiers, and chromatin

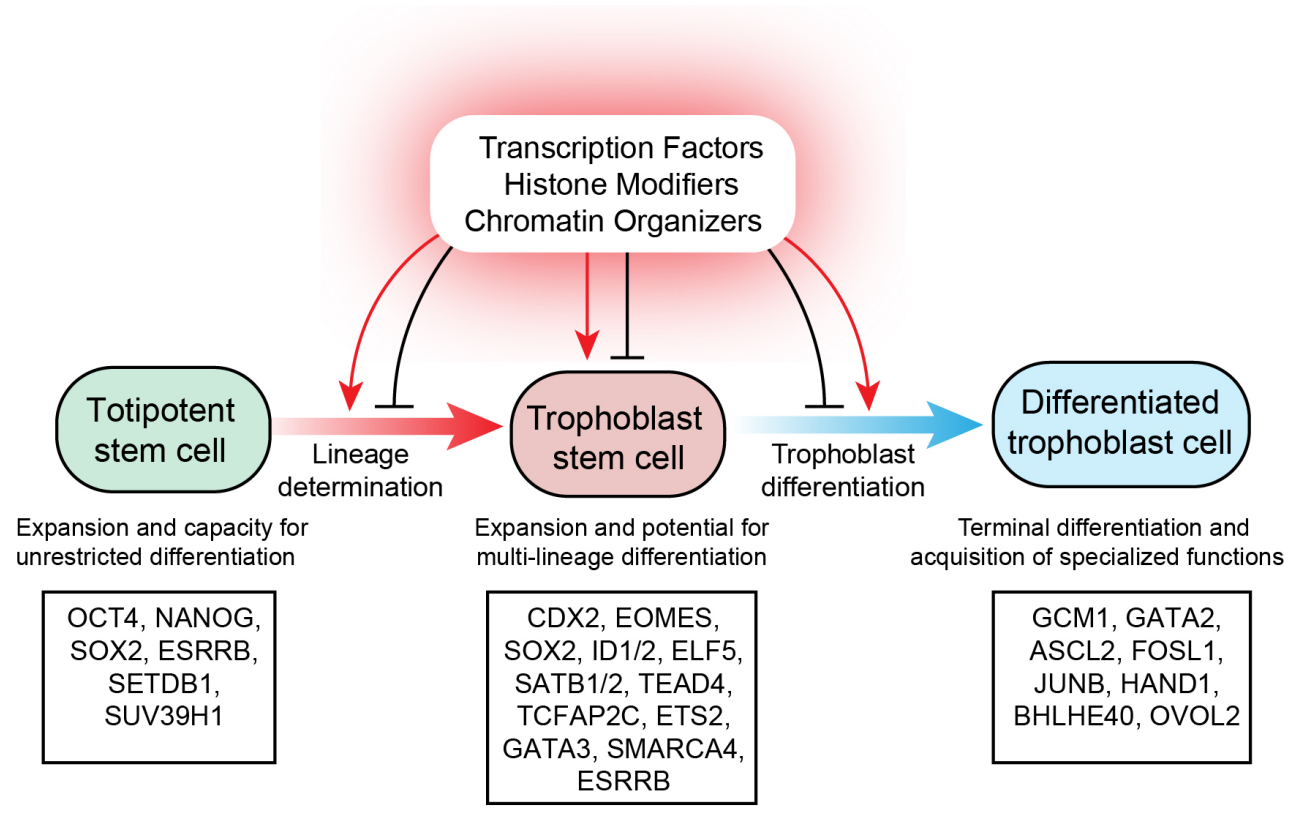


organizers cooperate to control totipotent stem cells, multipotent TS cells, and specialized trophoblast cells (Hemberger 2010; Maltepe et al., 2010; Wang et al., 2010; Rugg-Gunn 2012; Latos and Hemberger 2014; Paul and Knott 2014).

\section{Invasive trophoblast program}

The development of trophoblast cells is multi-directional. Trophoblast can specialize into cells with transport, hormone secreting, and invasive features. Cells exhibiting invasive capabilities are termed invasive trophoblast or in the case of the human as extravillous trophoblast. Invasive trophoblast cells possess gene expression profiles distinguishing themselves from other trophoblast cell lineages (Bilban et al., 2010; Apps et al., 2011). Two phenotypically distinct types of invasive trophoblast can be identified: i) cells moving between uterine stromal cells termed interstitial invasive trophoblast cells and ii) cells moving within uterine spiral arteries termed endovascular invasive trophoblast cells (Pijnenborg et al., 2006). In rodents, interstitial invasive trophoblast cells are characterized by their accumulation of glycogen (Teesalu et al., 1998; Vercruysse et al., 2006). Interstitial invasion is severely restricted in some rat strains, including the Brown Norway rat, which may be due to uterine progesterone resistance and attenuated decidua development (Konno et al., $2007,2010,2011)$. Both interstitial and endovascular invasive trophoblast cells contribute to uterine spiral artery modifications; however, based on their positioning they each have some unique targets and modes of action. Interstitial invasive trophoblast cells via their distribution throughout the uterine stroma likely possess a broad set of actions supportive of the maternal-fetal interface. The activities of endovascular invasive trophoblast cells are focused on the vasculature. They breach the spiral artery wall and propel themselves within the lumen of the vessel, where they replace the endothelium and can mimic components of an endothelial cell phenotype (Damsky and Fisher 1998; Rai and Cross 2014). There are species differences in this process and evidence that trophoblast replacement of the endothelium is incomplete, transitory, and that endothelial cells can repopulate the lining of the vessel wall (Pijnenborg et al., 2006; Ockleford 2010). Migratory features of invasive trophoblast are associated with their expression of proteins facilitating movement, including those proteins capable of modifying extracellular matrices. The mode of movement of interstitial versus endovascular trophoblast differs. In interstitial invasion - trophoblast cells dissociate and display elements of an epithelial to mesenchymal transformation as they penetrate the decidual stroma (Vicovac and Aplin 1996), whereas in endovascular invasion - cells maintain connectivity and exhibit an epithelial to endothelial-like transformation (Damsky and Fisher 1998). Aspects of the invasive trophoblast cell phenotype can be modeled in vitro; however, distinctions between the types of invasive trophoblast cells are more difficult to discern and are generally associated with acquisition of pseudovascular characteristics, which defines the endovascular invasive trophoblast cell population.

\section{Regulation of invasive trophoblast differentiation}

Considerable attention has been directed to elucidating pathways controlling the invasive trophoblast lineage. In this section, our discussion will be restricted to examples of conserved regula- tion demonstrated in vitro and in vivo using animal model systems and if available complemented with experimental findings showing relevance to human implantation/placentation.

\section{Phosphatidylinositol 3-kinase/AKT/FOSL1}

Several years ago, a linkage between Src family nonreceptor tyrosine kinases and phosphatidylinositol 3-kinase (PI3K) was established in differentiating rat TS cells (Kamei et al., 1997, 2002). PI3K is an intracellular enzyme responsible for the phosphorylation of phosphatidylinositol, which serves as a downstream activator of a signaling cascade controlling cell proliferation, differentiation, motility, metabolism, and survival (Cantley 2002). The LYN nonreceptor tyrosine kinase associates with PI3K and both proteins exhibit increases in enzymatic activity during trophoblast differentiation (Kamei et al., 1997, 2002; Kent et al., 2010). Small molecule inhibition of PI3K inhibits both endocrine and invasive activities of differentiating rat TS cells (Kamei et al., 2002; Kent et al., 2010). PI3K is an upstream regulator of the serine/threonine kinase, AKT. Inhibition of AKT also interferes with activation of the invasive trophoblast cell phenotype (Kent et al., 2011). AKT consists of three isoforms (AKT1, AKT2, AKT3). Each isoform is expressed in differentiating trophoblast cells and contributes to regulating the invasive trophoblast lineage (Kent et al., 2011). Both shared and isoform-specific actions characterize AKT signaling in differentiating trophoblast leading to complexities not yet fully appreciated (Kent et al., 2011; Haslinger et al., 2013).

There are numerous potential upstream activators of the PI3K/ AKT signaling cascade in trophoblast cells, consisting of growth factors, cytokines, and extracellular matrix constituents (Polheimer and Knöfler 2005; Knöfler 2010). EGF, HGF, IGF2, chorionic gonadotropin, and wingless (WNT) family ligands have been shown to stimulate invasive properties of human trophoblast or trophoblast cell lines, at least in part, through activation of the PI3K/AKT signaling pathway (Cartwright et al., 2002; Qu et al., 2004; Prast et al., 2008; Sonderegger et al., 2010; Pollheimer et al., 2011; Haslinger et al., 2013). However, demonstration of the involvement of any of these activators of PI3K/AKT in the regulation of in vivo intrauterine trophoblast invasion is lacking.

One intriguing downstream mediator of $\mathrm{PI}$ KK/AKT regulation of trophoblast invasiveness is the activator protein 1 (AP1) transcription factor component, FOSL1. PI3K/AKT signaling stabilizes the nuclear localization of FOSL1 (Kent et al., 2011). Trophoblast gene expression and invasion are regulated by FOSL1. In vitro knockdown of FOSL1 using specific short hairpin RNAs (shRNAs) disrupts the expression of key genes encoding proteins associated with dissolution of extracellular matrices, cell migration, and vascular remodeling and inhibits trophoblast cell migration through extracellular matrices (Kent et al., 2011). Furthermore, in vivo knockdown of FOSL1 in the rat using trophoblast-specific lentiviral delivery of specific FOSL1 shRNAs significantly reduced the depth of trophoblast invasion into the uterus (Kent et al., 2011). Such an action of FOSL1 was not evident from mouse mutagenesis experiments (Schreiber et al., 2000). FOSL1 was shown to regulate mouse placentation but a clue to its actions on the invasive trophoblast lineage was not forthcoming. These results do not diminish FOSL1 as a regulator of the invasive trophoblast phenotype but instead highlight the limitations of using the mouse as a model system for investigating the invasive trophoblast lineage. In fact, the pro-invasive action of FOSL1 is conserved in human trophoblast (Renaud et al., 2014). 
FOSL1 is localized to extravillous trophoblast at the leading edge of trophoblast columns penetrating the uterine decidua. Interestingly, two other FOS family transcription factors, FOS and FOSB, restrain the actions of FOSL1 and instead are prominently expressed in proliferating trophoblast cells embedded within the core of the trophoblast columns (Renaud et al., 2014).

Collectively, the data suggest the participation of a conserved $\mathrm{PI}$ 3K/AKT/FOSL1 pathway in the regulation of invasive trophoblast. Upstream activation of $\mathrm{PI}$ KK/AKT signaling and downstream events, including FOSL1 partners and specific transcriptional targets, mediating invasive trophoblast differentiation remain to be elucidated.

\section{Notch}

The Notch signaling pathway is a highly conserved cell-cell communication system directing embryonic development. Notch signaling components include a family of receptors (NOTCH1-4) and membrane-associated ligands of the DLL and JAG families (Hori et al., 2013). Signal transduction is activated when a ligandexpressing cell apposes a NOTCH-expressing cell impacting potentially a broad spectrum of cellular processes (e.g. survival, proliferation, differentiation, motility, and vascular specification). Mouse and human trophoblast cells express components of the Notch signaling pathway (Nakayama et al., 1997; Hunkapiller et al., 2011; Haider et al., 2014). Selective genetic inactivation of Notch2 in mouse trophoblast lineages results in disruptions in placentation, including failed trophoblast cell invasion of uterine spiral arteries and impaired perfusion of the placenta (Hunkapiller et al., 2011). In vitro experimentation has demonstrated the importance of Notch signaling in human trophoblast cell biology but led to differing conclusions. In one report, disruption of Notch signaling with a small molecule inhibitor interfered with trophoblast invasive properties and impaired acquisition of a pseudo-vascular phenotype directly supporting the Notch2mutant mouse phenotype (Hunkapiller et al., 2011), whereas another report highlighted the importance of Notch signaling in maintaining trophoblast proliferation and its antagonism of trophoblast motility and invasive properties (Haider et al., 2014). These in vitro experimental outcomes point to the importance of Notch signaling in trophoblast cells and also its dynamic nature. Multiple NOTCH receptors and ligands expressed by several placentation site-associated cell types each possessing gestational stage-specific expression profiles creates complexities for planning in vitro experiments designed to recapitulate aspects of in vivo trophoblast cell development.

\section{Oxygen}

Cells require oxygen and possess intricate and highly conserved mechanisms for adapting to oxygen deprivation (Semenza 2010). Central to cellular adaptations to low oxygen is a transcriptional complex referred to as hypoxia-inducible factor (HIF). HIF is composed of an oxygen labile alpha subunit (HIF1A or HIF2A) and a constitutive partner referred to as HIF1 beta (HIF1B, also called aryl hydrocarbon nuclear translocator, ARNT). The HIF alpha subunit is vulnerable to degradation at oxygen replete conditions. In contrast, at conditions of oxygen scarcity the HIF transcriptional complex is stabilized and activates target genes encoding proteins essential for cellular adaptation to low oxygen. Definitions of a couple of terms associated with oxygen homeostasis are required before we proceed. Normoxia represents a condition of "normal" oxygen availability. Hypoxia is a condition associated with low oxygen ten- sion, especially one that evokes the HIF-mediated cellular adaptive response. Importantly, a specific oxygen tension cannot be used to define hypoxia or normoxia. These are relative terms and are absolutely dependent upon cell type and physiological or pathological setting. It should be appreciated that under physiological conditions hypoxia is a transient homeostatic process corrected by an assortment of cellular and systemic adaptations. Chronic hypoxia is a pathological event associated with failures in adaptation. These fundamental principles need to be considered in designing experiments to investigate the impact of oxygen tension on trophoblast cell biology. Unfortunately, attempts to model hypoxia in vitro have been fraught with numerous inaccurate assumptions and misleading interpretations (see Tuuli et al., 2011 for additional discussion).

Oxygen tensions at the placentation site change during the course of gestation (Zamudio, 2003). Establishment of the hemochorial interface is the pivotal event determining trophoblast cell oxygen exposure. Oxygen increases once trophoblast-vascular connectivity is established. It has also become evident that oxygen is an orchestrator of placental morphogenesis (Dunwoodie 2009). Such insight has been gained from mouse mutagenesis of several key regulators of oxygen homeostasis, including HIF1A, HIF2A, HIF1B, EGLN1, VHL, and CITED2 (Gnarra et al., 1997; Kozak et al., 1997; Adelman et al., 2000; Cowden Dahl etal., 2005a; Maltepe et al., 2005; Takeda et al., 2006; Withington et al., 2006). Additional understanding has been achieved from using oxygen tension as an in vivo experimental tool to investigate placentation site-associated adaptations in the rat (Rosario et al., 2008). Exposure of pregnant rats to $10-11 \%$ oxygen from the onset of embryo implantation until midgestation results in profound effects on the maternal-fetal interface (Ho-Chen et al., 2007; Rosario et al., 2008). The hypoxic conditions drive increase in uterine mesometrial vascularity, uterine spiral arterial remodeling, and dramatic increases in the depth of intrauterine endovascular invasive trophoblast cell penetration (Fig. 3). This environmental challenge accelerated and exaggerated changes at the placentation site that would not normally occur until the latter stages of pregnancy. Activation of the invasive trophoblast lineage required exposure to hypoxia between gestation days 8.5 and 9.5. This critical window of in vivo sensitivity to oxygen correlates with the initiation of essential trophoblast cell differentiation leading to formation of the bi-compartmental rat placenta. Hypoxia results in preferential expansion of the junctional zone and its resident invasive trophoblast cell population, which is situated at the maternal interface, and a proportional reduction in the size of the labyrinth zone (Rosario et al., 2008; Chakraborty et al., 2011). This is a conserved adaptive response. In vivo hypoxia activation of the invasive trophoblast lineage has also been observed in primates (Zhou et al., 1993; Kadyrov et al., 2003). Alternatively, others have used in vivo chronic hypoxia to overwhelm adaptive responses and create placental injury (Tomlinson etal., 2010; Lai et al., 2011). Thus, oxygen availability can serve as context-dependent instructive or pathological signals affecting placentation. In general, trophoblast cells migrate toward higher oxygen tensions (Jauniaux et al., 2001).

Oxygen tension is also a potent regulator of in vitro trophoblast cell behavior, including development of the invasive trophoblast lineage. Fisher and colleagues first showed that low oxygen tension (2 percent) promoted first trimester human trophoblast proliferation, whereas atmospheric oxygen (21 percent at sea level) stimulated differentiation (Genbacev et al., 1996, 1997). Since then an assortment of observations have been made on trophoblast cell 
responses to low oxygen, including seemingly contradictory findings. It is now apparent that oxygen concentration and duration of exposure can have fundamentally different effects on trophoblast cell behavior (Tuuli et al., 2010; Zhou et al., 2011). Additionally, the origin and characteristics of the trophoblast cell (e.g. primary trophoblast, gestational age, immortalized trophoblast cell line, trophoblast cancer cell) influences its responses to oxygen availability. Rodent TS cells have proven to be a robust in vitro model system for studying trophoblast cell adaptations to low oxygen (Cowden Dahl et al., 2005a,b; Chakraborty et al., 2011; Zhou et al., 2011). Gradients in oxygen tension can differentially stimulate trophoblast cell proliferation or trophoblast cell differentiation (Zhou et al., 2011). Very low oxygen concentrations (0.5-1.5\%) activate development of the invasive trophoblast lineage (Cowden Dahl et al., 2005b; Chakraborty et al., 2011). This differentiation event is associated with decreased cell-cell adhesion, upregulation of matrix metalloproteinases, and increased cellular movement through extracellular matrices; and is dependent upon activation of the HIF signaling pathway. The targets downstream of HIF transcriptional regulation in hypoxia-exposed TS cells have not been identified but should include genes controlling key stages in the differentiation of the invasive trophoblast lineage and also the activation of homeostatic regulatory processes designed to promote trophoblast cell survival and function. Activation of endothelial nitric oxide synthase and production of nitric oxide is an adaptation used in the mouse placenta to prevent local hypoxia (Schaffer et al., 2006). There is also evidence that non-canonical HIF signaling contributes to the regulation of trophoblast differentiation (Choi et al., 2013) and that hypoxia can affect trophoblast differentiation independent of HIF (Tache et al., 2013). Links between hypoxia and epigenetic regulation, including histone acetylation and DNA methylation, have been investigated in trophoblast cells (Maltepe et al., 2005; Yuen et al., 2013). Interestingly, in human trophoblast cells hypoxia-sensitive DNA methylation regions are enriched for AP1 binding motifs (Yuen et al., 2013), thus potentially connecting AP1, including FOSL1, and hypoxia/HIF regulatory pathways in trophoblast cell adaptive mechanisms.

In summary, TS cells present during the formative stages of
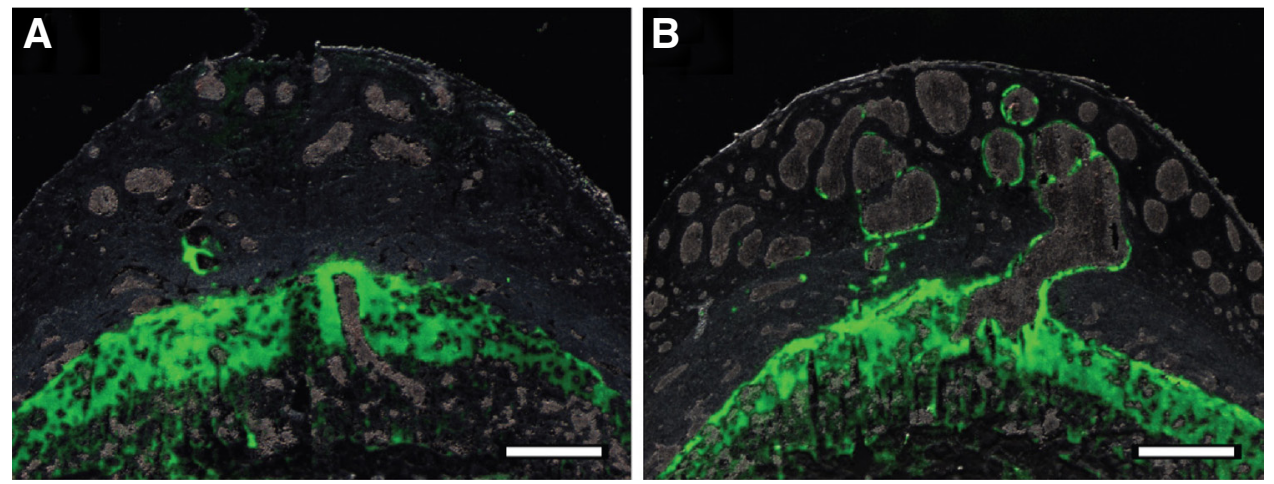

Fig. 3. Maternal hypoxia stimulates trophoblast invasion into uterine spiral arteries of the rat. Wild-type female rats were mated to homozygous ch $\beta A$-enhanced green fluorescent protein (EGFP) transgenic male rats and exposed to an atmospheric oxygen tension 21 percent at sea level (A) or hypoxia (10-11\%; gestation day 6.5 to day 13.5 (B). Placentation sites were examined on gestation day 13.5 and uterine mesometrial compartments inspected for EGFP positive cells. Note that maternal hypoxia stimulated the invasion of extraembryonic-derived EGFP positive cells deep into maternal uterine spiral arteries, representing a potentially effective placental-associated adaptation to an environmental challenge. Scale bar, $0.5 \mathrm{~mm}$. Adapted from Rosario et al., 2008. placentation are characterized by their plasticity. They can differentiate into trophoblast cells targeted to the uterine vasculature or alternatively into trophoblast cells dedicated to nutrient transport, effectively establishing the functional limits for placental performance and the milieu for fetal growth and development. Oxygen delivery to the TS cell niche contributes to decision-making governing trophoblast cell differentiation. Low oxygen activates HIF signaling and favors differentiation directed toward the invasive trophoblast cell lineage. Thus factors controlling oxygen delivery to the TS cell niche, especially NK cells (see above), have a major influence on the organization of the maternal-fetal interface.

\section{Disease processes associated with disruptions in uterine spiral artery remodeling}

Failures in trophoblast-directed uterine spiral artery remodeling have been reported in diseased human pregnancies diagnosed with preeclampsia, Hemolysis, Elevated Liver enzymes, Low Platelets (HELLP) syndrome, and intrauterine growth restriction (Kaufmann et al., 2003; Pijnenborg et al., 2006). These pathologies have been a major driver of placental research. There are exquisite descriptions of the phenomenology surrounding the diseases but much less insight into their actual etiologies. The lack of progress is certainly associated with the multifactorial nature of any pregnancy related event. The embryo, its ability to give rise to multiple trophoblast lineages, and the host maternal environment in which the embryo develops each contribute to the manifestation of the disease. Two routes of inquiry are apparent: i) identify potential sensitive junctures in normal developmental processes, which may impact susceptibility to disease; ii) directly study the disease and determine how the disruption of candidate regulators leads to disease. Strategies for studying trophoblast-directed uterine spiral artery remodeling have been provided above. Investigations on mechanisms underlying pregnancy-related diseases are inherently confounded because key events associated with the ontogeny of the disease pre-date diagnosis. Diseased tissue specimens are affected by a failed placentation (e.g. hypoxia, inflammation) and thus compromise acquisition of mechanistic insights into etiology from any phenotypic analysis. Genetic analyses have offered an alternative approach (van Dijk and Oudejans 2013).

Several genetic screens have been performed to establish linkages between pregnancy-related diseases associated with impairments in trophoblast cell invasion and uterine spiral artery remodeling, including preeclampsia and the HELLP syndrome (van Dijk and Oudejans 2013). Among these efforts, a couple of genes have been pursued and complemented with functional analyses leading to the identification of previously unappreciated regulatory pathways.

\section{Stox 1}

A polymorphism at the STOX1 locus was identified in genetic screens of families with severe preeclampsia and intrauterine growth restriction (van Dijk et 
al., 2005). The STOX1 protein possesses a winged helix domain present in FOX family transcription factors, suggesting that STOX1 may contribute to the regulation of gene expression. The polymorphism affects the amino acid structure of the STOX1 DNA binding domain $(\mathrm{Y} 153 \mathrm{H})$. The $\mathrm{H}$ isoform is associated with the diseased state. It is expressed in extravillous trophoblast and specifically targets and promotes transcription of the CTNNA3 gene. CTNNA3 encodes a cell-cell adhesion molecule, $\alpha$-T-catenin, and restrains the invasive properties of trophoblast cells (van Dijk et al., 2010). These observations are further supported by experiments using a transgenic mouse model. Pregnant female mice possessing conceptuses overexpressing STOX1 exhibit preeclampsia-like symptoms (Doridot et al., 2013). Although placentation was altered in the STOX1 overexpressing conceptuses, a description of invasive trophoblast cells and uterine spiral artery remodeling was not reported. Most interestingly, nuclear localization of the STOX1 protein is regulated by AKT (van Dijk et al., 2010). AKTmediated STOX1 phosphorylation prevents entry of STOX1 into the nucleus, consistent with the pro-invasive role of AKT signaling in trophoblast cells.

\section{HELLP long non-coding RNA}

A genetic screen of familial HELLP syndrome led to the identification of mutations in a gene encoding a long non-coding RNA specifically expressed in extravillous trophoblast (van Dijk et al., 2012). Initial evidence indicates that the HELLP long noncoding RNA promotes proliferation and inhibits differentiation into the extravillous invasive trophoblast phenotype. This finding opens an avenue for future exploration into a potentially novel mechanism controlling trophoblast differentiation.

\section{Other candidate genes}

A candidate gene approach has also been used to elucidate mechanisms associated with disruptions in trophoblast cell invasion and preeclampsia. Two examples will be discussed. Experimental evidence has accumulated suggesting that catechol-O-methyltransferase (COMT) and corin serine peptidase (CORIN) are modulators of trophoblast cell invasion and disrupted in preeclampsia (Kanasaki et al., 2008; Lee et al., 2010; Cui et al., 2012). Their potential involvement in the etiology of the pregnancy-associated disease surfaced from examination of tissues from preeclamptic patients and has been bolstered through phenotypic investigations of genetically modified rodent models. COMT is expressed in the placenta and methylates several circulating hormones, including catechol estrogens, and is responsible for the generation of 2-methoxyestradiol (2-ME). 2-ME synergizes with hypoxia to promote trophoblast cell invasive properties (Lee et al., 2010). Preeclamptic patients exhibit decreased placental COMT activities and disruption of the Comt gene in the mouse is associated with a preeclampsia-like phenotype in pregnant mice (Kanasaki et al., 2008). Polymorphisms in the COMT gene affecting COMT expression or COMT enzymatic activity may contribute to the development of preeclampsia (Shenoy et al., 2010). In contrast, the CORIN-associated preeclamptic phenotype reflects disruptions in the maternal environment. CORIN is expressed in the uterus and acts to generate biologically active atrial natriuretic peptide (ANP). ANP stimulates in vitro trophoblast cell invasion through extracellular matrices and either CORIN or ANP deficiencies in the mouse result in deficits in both trophoblast invasion and uterine spiral artery remodeling and are characterized by preeclamptic-like symptoms (Cui et al., 2012). Uteri from preeclamptic patients express less CORIN and some preeclamptic patients possess polymorphisms negatively affecting

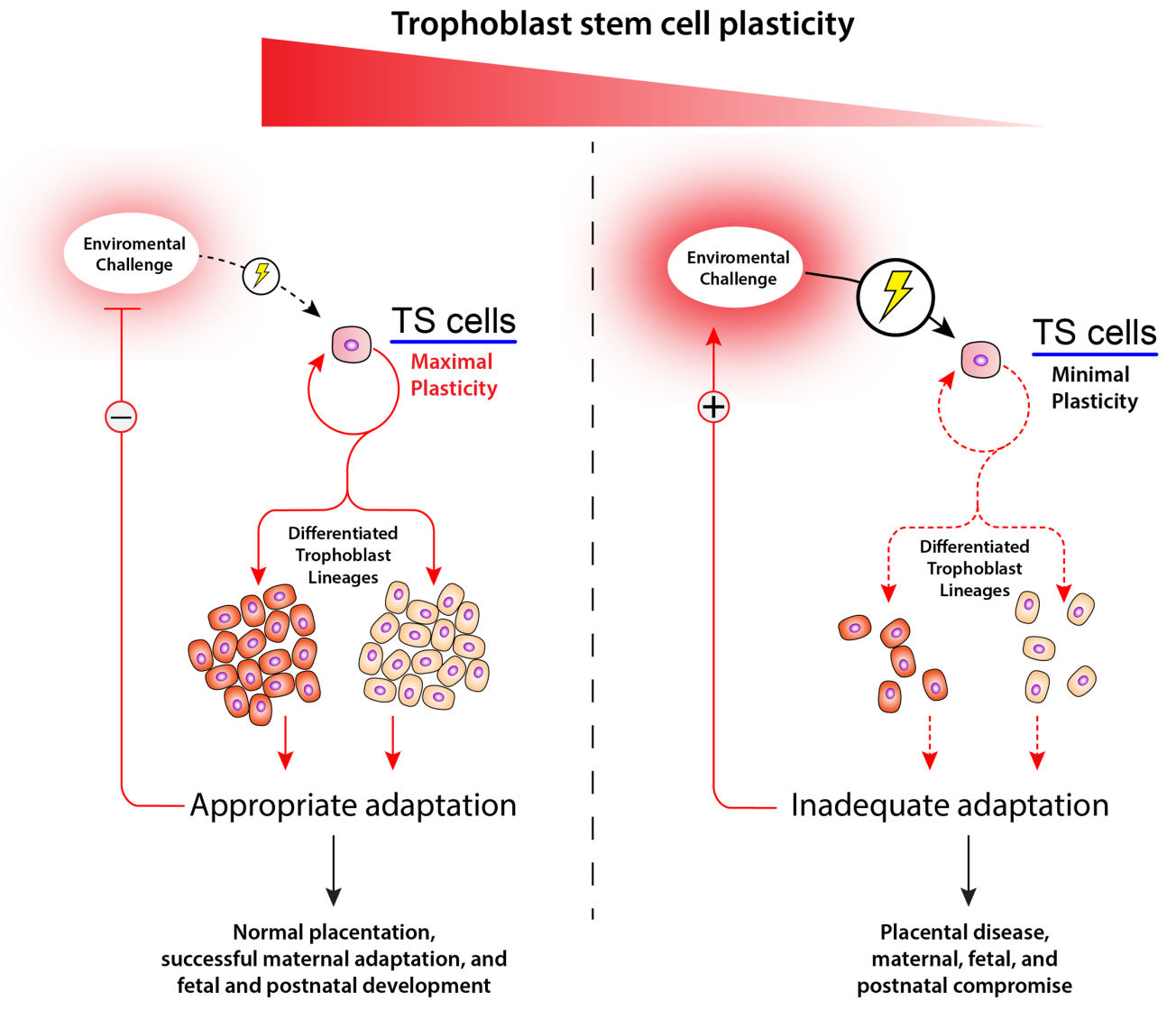

Fig. 4. Trophoblast stem (TS) cell plasticity and placental disease. Environmental challenges, including nutrient availability, at the maternal-fetal interface direct the decision-making of TS cells. TS cells possess the capacity to self-renew, die, become quiescent, or differentiate into specialized trophoblast lineages. A successful pregnancy is associated with robust and gestation stage-appropriate homeostatic responses to environmental challenges resulting in effective organization of the placentation site, maternal adaptations and normal progression of fetal development and healthy offspring. In contrast, we propose that placental disease is associated with a TS cell that lacks plasticity and the ability to effectively adapt to environmental challenges, which activates a positive feedback loop sustaining and potentially intensifying the environmental challenge, resulting in failures in placentation and maternal, fetal, and postnatal compromise. 
CORIN enzymatic activity (Cui et al., 2012), further supporting a role for CORIN in the etiology of preeclampsia.

\section{Overview}

Diseases affecting trophoblast invasion and uterine spiral artery remodeling are examples of classic positive feedback paradigms. Early failures in the process of uterine spiral artery remodeling lead to hypoxia and inflammation that perpetuate and exacerbate the deficits (Renaud et al., 2011; Cotechini et al., 2014) and are not remedied until the pregnancy is terminated and the protagonist placenta removed. It is expected that clarity will be achieved as we gain insights into both the physiology and pathophysiology of uterine spiral artery remodeling.

\section{Final thoughts on adaptations at the maternal-fetal interface}

Plasticity and the ability to adapt to environmental challenges are favorable attributes for pregnancy success (see Fig. 4). Intrinsic to any adaptation affecting pregnancy is the control of the decision-making process directing multi-lineage differentiation of trophoblast stem cell populations. These stem cells can selfrenew, die, become quiescent, or differentiate and assume one of several specialized functions within the placenta. This flexibility is gestation-stage dependent with greater capacity for adaptation during early versus later phases of pregnancy and it ensures that the placentation site is optimally organized to facilitate fetal growth and development. Failures in early organizational decisions yield rigidity and inability to effectively adapt to later challenges. The entry points for understanding placentation site-associated plasticity are homeostatic mechanisms that all cells utilize to optimize their survival when exposed to environmental stressors. Some elements of this fundamental adaptive process can be modeled in a dish and are most meaningful when complemented with investigations using animal models (Bonney 2013; Clark 2014). Logically, placental disease results when adaptive responses at the implantation/placentation site fail or are inappropriate, thus sustaining or intensifying the environmental challenge and leading to maternal, fetal, and postnatal compromise. Determining whether a placenta is destined for success or failure, especially considering the importance of the placenta to the growth and development of the fetus and its future postnatal health, is inherently complicated but fundamental to improving human health.

\section{Acknowledgements}

We would like to thank past and current members of our laboratory for contributing to our research effort. This work was supported by grants from the National Institutes of Health (HD020676, MJS; HD072100, MAKR) and fellowships from the American Heart Association (DC, KK), the Japan Society for the Promotion of Science (KK), and the Canadian Institutes of Health Research (SJR).

\section{References}

ABELLAN, GRANGER DA, JOHNSON NL, VINCENT-JORDAN N, DIBBLE CF, and JOHNSON GL (2009). Trophoblast stem cell maintenance by fibroblast growth factor 4 requires MEKK4 activation of Jun N-terminal kinase. Mol Cell Biol 29: 2748-2761.

ABELLAN, JORDAN NV, HUANG W, PRATA, MIDLAND AA, JOHNSONNL, GRANGER DA, MIECZKOWSKI PA, PEROU CM, GOMEZ SM, LI L, and JOHNSON GL (2011). MAP3K4/CBP-regulated H2B acetylation controls epithelial-mesenchymal transition in trophoblast stem cells. Cell Stem Cell 8: 525-537.

ADACHI K, NIKAIDO I, OHTA H, OHTSUKA S, URA H, KADOTA M, WAKAYAMA T, UEDAH, and NIWAH (2013). Context-dependent wiring of Sox2 regulatory networks for self-renewal of embryonic and trophoblast stem cells. Mol Cell 52: 380-392.

ADAMSON SL, LUY, WHITELEY KJ, HOLMYARD D, HEMBERGERM, PFARRER C, and CROSS JC (2002). Interactions between trophoblast cells and the maternal and fetal circulation in the mouse placenta. Dev Biol 250: 358-373.

ADELMAN DM, GERTSENSTEIN M, NAGYA, SIMON MC, and MALTEPE E (2000). Placental cell fates are regulated in vivo by HIF-mediated hypoxia responses. Genes Dev 14: 3191-3203.

AIN R, CANHAM LN, and SOARES MJ (2003). Gestational stage-dependent intrauterine trophoblast cell invasion in the rat and mouse: novel endocrine phenotype and regulation. Dev Biol 260: 176-190.

AIN R, CANHAM LN, and SOARES MJ (2005). Dexamethasone-induced intrauterine growth restriction impacts the placental prolactin family and the insulin-like growth factor-II/Akt signaling pathway. J Endocrinol 185: 253-263.

AIN R, TRINH M-L, and SOARES MJ (2004). Interleukin-11 signaling is required for the differentiation of natural killer cells at the maternal-fetal interface. Dev Dyn 231: 700-708.

ALDER O, LAVIALF, HELNESS A, BROOKES E, PINHO S, CHANDRASHEKRANA, ARNAUD P, POMBO A, O'NEILL L, and AZUARA V (2010). Ring1B and Suv39h1 delineate distinct chromatin states at bivalent genes during early mouse lineage commitment. Development 137: 2483-2492.

AMITA M, ADACHI K, ALEXENKO AP, SINHA S, SCHUST DJ, SCHULZ LC, ROBERTS RM, and EZASHI T (2013). Complete and unidirectional conversion of human embryonic stem cells to trophoblast by BMP4. Proc Natl Acad Sci USA 110: E1212-E1221.

AMOROSO EC (1959). Comparative anatomy of the placenta. Ann NY Acad Sci 75: 855-872.

APLIN JD (2006). In vitroanalysis of trophoblast invasion. Methods Mol Med122:45-57.

APPS R, SHARKEY A, GARDNER L, MALE V, TROTTER M, MILLER N, NORTH R, FOUNDS S, and MOFFETT A (2011). Genome-wide expression profile of first trimester villous and extravillous human trophoblast cells. Placenta 32: 33-43.

ASANOMAK, KUBOTAK, CHAKRABORTY D, RENAUD SJ, WAKE N, FUKUSHIMA K, SOARES MJ, and RUMI MAK (2012). SATB homeobox proteins regulate trophoblast stem cell renewal and differentiation. J Biol Chem 287: 2257-2268.

ASANOMA K, RUMI MAK, KENT LN, CHAKRABORTY D, RENAUD SJ, WAKE N, LEE D-S, KUBOTA K, and SOARES MJ (2011). FGF4-dependent stem cells derived from rat blastocysts differentiate along the trophoblast lineage. Dev Biol 351: 110-119.

ASHKAR AA and CROY BA (2001). Functions of uterine natural killer cells are mediated by interferon gamma production during murine pregnancy. Semin Immunol 13: $235-241$

BARBER EM and POLLARD JW (2003). The uterine NK cell population requires IL15 but these cells are not required for pregnancy nor the resolution of a Listeria monocytogenes infection. J Immunol 171: 37-46.

BILBANM, TAUBERS, HASLINGERP, POLLHEIMER J, SALEHL, PEHAMBERGER H, WAGNER O, and KNÖFLER M (2010). Trophoblast invasion: assessment of cellular models using gene expression signatures. Placenta 31: 989-996.

BONNEY EA (2013). Demystifying animal models of adverse pregnancy outcomes: touching bench and bedside. Am J Reprod Immunol 69: 567-584.

CANTLEY LC (2002). The phosphoinositides 3-kinase pathway. Science 296: 1655-1657.

CARTWRIGHT JE, TSE WK, WHITLEY GS (2002). Hepatocyte growth factor induced human trophoblast motility involves phosphatidylinositol-3-kinase, mitogen-activated protein kinase, and inducible nitric oxide synthase. Exp Cell Res 279:219-226.

CERDEIRA AS, RAJAKUMAR A, ROYLE CM, LO A, HUSAIN Z, THADHANI RI, SUKHATME VP, KARUMANCHI SA, and KOPCOW HD (2013). Conversion of peripheral blood NK cells to a decidual NK-like phenotype by a cocktail of defined factors. J Immunol 190: 3939-3948.

CHAKRABORTY D, RUMI MAK, KONNO T, and SOARES MJ (2011). Natural killer cells direct hemochorial placentation by regulating HIF-dependent trophoblast lineage decisions. Proc Natl Acad Sci USA 108: 16295-16300.

CHOI HJ, SANDERS TA, TORMOS KV, AERI K, TSAI JD, PARK AM, GONZALEZ J, RAJAH AM, LIU X, QUINONEZ DM, RINAUDO PF, and MALTEPE E (2013). 
ECM-dependent HIF induction directs trophoblast stem cell fate via LIMK1-mediated cytoskeletal rearrangement. PLoS One 8: e56949.

CHOI I, CAREY TS, WILSON CA, and KNOTT JG (2013). Evidence that transcription factor AP-2 $\gamma$ is not required for Oct4 repression in mouse blastocysts. PLOS One 8: e65771.

CHUONG EB, RUMI MA, SOARES MJ, and BAKER JC (2013). Endogenous retroviruses function as species-specific enhancer elements in the placenta. Nat Genet 45: 325-329.

CLARKDA (2014). The use and misuse of animal analog models of human pregnancy disorders. J Reprod Immunol 103: 1-8.

COCKBURN K and ROSSANT J (2010). Making the blastocyst: lessons from the mouse. J Clin Invest 120: 995-1003.

COTECHINI T, KOMISARENKO M, SPEROU A, MACDONALD-GOODFELLOW S, ADAMS MA, and GRAHAM CH (2014). Inflammation in rat pregnancy inhibits spiral artery remodeling leading to fetal growth restriction and features of preeclampsia. $J$ Exp Med 211: 165-179.

COWDEN DAHL KD, FRYER BH, MACK FA, COMPERNOLLE V, MALTEPE E, ADELMAN DM, CARMELIET P, and SIMON MC (2005a). Hypoxia-inducible factors $1 \alpha$ and $2 \alpha$ regulate trophoblast differentiation. Mol Cell Biol 25: 10479-10491.

COWDEN DAHL KD, ROBERTSON SE, WEAVER VM, and SIMON MC (2005b). Hypoxia-inducible factor regulates $\alpha v \beta 3$ integrin cell surface expression. $\mathrm{Mol}$ Biol Cell 16: 1901-1912.

CUI Y, WANG W, DONG N, LOU J, SRINIVASAN DK, CHENG W, HUANG X, LIU M, FANG C, PENG J, CHEN S, WU S, LIU Z, DONG L, ZHOU Y, and WU Q (2012). Role of corin in trophoblast invasion and uterine spiral artery remodelling in pregnancy. Nature 484: 246-250.

DAMBAEVA SV, DURNING M, ROZNER AE, and GOLOS TG (2012). Immunophenotype and cytokine profiles of rhesus monkey CD56 bright and CD56 dim decidual natural killer cells. Biol Reprod 86: 1-10.

DAMSKY CH and FISHER SJ (1998). Trophoblast pseudo-vasculogenesis: faking it with endothelial adhesion receptors. Curr Opin Cell Biol 10: 660-666.

DORIDOTL, PASSETB, MÉHATSC, RIGOURDV, BARBAUXS, DUCATA, MONDON F, VILOTTE M, CASTILLE J, BREUILLER-FOUCHÉ M, DANIEL N, LE PROVOST F, BAUCHET AL, BAUDRIE V, HERTIG A, BUFFAT C, SIMEONI U, GERMAIN G, VILOTTE JL, and VAIMAN D (2013). Preeclampsia-like symptoms induced in mice by fetoplacental expression of STOX1 are reversed by aspirin treatment. Hypertension 61: 662-668.

DUNWOODIE SL (2009). The role of hypoxia in development of the mammalian embryo. Dev Cell 17: 755-773.

EASTABROOK G, HU Y, and VON DADELSZEN P (2008). The role of decidual natural killer cells in normal placentation and in the pathogenesis of preeclampsia. J Obstet Gynaecol Can 30:467-476.

ERLEBACHER A, PRICE KA, and GLIMCHER LH (2004). Maintenance of mouse trophoblast stem cell proliferation by TGF-beta/activin. Dev Biol 275: 158-169.

EZASHI T, TELUGU BP, and ROBERTS RM (2012). Model systems for studying trophoblast differentiation from human pluripotent stem cells. Cell Tissue Res 349: 809-824.

GENBACEV O, DONNE M, KAPIDZIC M, GORMLEY M, LAMB J, GILMORE J, LAROCQUE N, GOLDFIEN G, ZDRAVKOVIC T, MCMASTER MT, and FISHER SJ (2011). Establishment of human trophoblast progenitor cell lines from the chorion. Stem Cells 29: 1427-36.

GENBACEV O, JOSLIN R, DAMSKY CH, POLLIOTTI BM, and FISHER SJ (1996). Hypoxia alters early gestation human cytotrophoblast differentiation/invasion in vitro and models the placental defects that occur in preeclampsia. $J$ Clin Invest 97: 540-550.

GENBACEV O, ZHOUY, LUDLOW JW, and FISHER SJ (1997). Regulation of human placental development by oxygen tension. Science 277: 1669-1672.

GNARRA JR, WARD JM, PORTER FD, WAGNER JR, DEVOR DE, GRINBERG A, EMMERT-BUCKMR, WESTPHALH, KLAUSNERRD, and LINEHAN WM (1997). Defective placental vasculo-genesis causes embryonic lethality in VHL-deficient mice. Proc Natl Acad Sci USA 94: 9102-9107.

GRAHAM CH, HAWLEY TS, HAWLEY RG, MACDOUGALLJR, KERBEL RS, KHOO $\mathrm{N}$, and LALA PK (1993). Establishment and characterization of first trimester human trophoblast cells with extended lifespan. Exp Cell Res 206: 204-211.

GUIMOND MJ, LUROSS JA, WANG B, TERHORST C, DANIAL S, and CROY BA (1997). Absence of natural killer cells during murine pregnancy is associated with reproductive compromise in TgE26 mice. Biol Reprod 56: 169-179.

HAIDER S, MEINHARDT G, VELICKY P, OTTI GR, WHITLEY G, FIALA C, POLLHEIMER J, and KNÖFLER M (2014). Notch signaling plays a critical role in motility and differentiation of human first trimester cytotrophoblasts. Endocrinology 155: 263-274.

HANNA J, GOLDMAN-WOHL D, HAMANI Y, AVRAHAM I, GREENFIELD C NATANSON-YARON S, PRUS D, COHEN-DANIEL L, ARNON TI, MANASTER I, GAZIT R, YUTKIN V, BENHARROCH D, PORGADOR A, KESHET E, YAGEL $S$, and MANDELBOIM O (2006). Decidual NK cells regulate key developmental processes at the human fetal-maternal interface. Nat Med 12: 1065-1074.

HARRIS LK (2010). Trophoblast-vascular cell interactions in early pregnancy: how to remodel a vessel. Placenta 31 Suppl: S93-S98.

HARRIS LK (2011). Transformation of the spiral arteries in human pregnancy: key events in the remodelling timeline. Placenta 32 Suppl 2: S154-S158.

HASLINGER P, HAIDER S, SONDEREGGER S, OTTEN JV, POLLHEIMER J, WHITLEY G, and KNÖFLER M (2013). AKT isoforms 1 and 3 regulate basal and epidermal growth factor-stimulated SGHPL-5 trophoblast cell migration in humans. Biol Reprod 88: 54.

HAYASHIY, FURUEMK, TANAKAS, HIROSEM, WAKISAKAN, DANNOH, OHNUMA $\mathrm{K}$, OEDA S, AIHARA Y, SHIOTA K, OGURA A, ISHIURA S, and ASASHIMA M (2010). BMP4 induction of trophoblast from mouse embryonic stem cells in defined culture conditions on laminin. In vitro Cell Dev Biol Anim 46: 416-430.

HAZAN AD, SMITH SD, JONES RL, WHITTLE W, LYE SJ, and DUNK CE (2010). Vascular-leukocyte interactions: mechanisms of human decidual spiral artery remodeling in vitro. Am J Pathol 177: 1017-1030.

HEMBERGER M (2010). Genetic-epigenetic intersection in trophoblast differentiation: implications for extraembryonic tissue function. Epigenetics 5: 24-29.

HEMBERGER M, UDAYASHANKAR R, TESAR P, MOORE H, and BURTON GJ (2010). ELF5-enforced transcriptional networks define an epigenetically regulated trophoblast stem cell compartment in the human placenta. Hum Mol Genet 19: 2456-2467.

HIBY SE, WALKER JJ, O'SHAUGHNESSY KM, REDMAN CW, CARRINGTON M, TROWSDALE J, and MOFFETT A (2004). Combinations of maternal KIR and fetal HLA-C genes influence the risk of preeclampsia and reproductive success. J Exp Med 200: 957-965.

HO-CHEN JK, BUSTAMANTE JJ, and SOARES MJ (2007). Prolactin-like protein-F subfamily of placental hormones/cytokines: responsiveness to maternal hypoxia. Endocrinology 148: 559-565.

HOME P, RAY S, DUTTA D, BRONSHTEYN I, LARSON M, and PAUL S (2009). GATA3 is selectively expressed in the trophectoderm of peri-implantation embryo and directly regulates Cdx2 gene expression. J Biol Chem 284: 28729-28737.

HOME P, SAHAB, RAY S, DUTTAD, GUNEWARDENAS, YOO B, PALA, VIVIAN JL, LARSON M, PETROFF M, GALLAGHER PG, SCHULZ VP, WHITE KL, GOLOS TG, BEHR B, and PAUL S (2012). Altered subcellular localization of transcription factor TEAD4 regulates first mammalian cell lineage commitment. Proc Natl Acad Sci USA 109: 7362-7367.

HORI K, SEN A, and ARTAVANIS-TSAKONAS S (2013). Notch signaling at a glance. $J$ Cell Sci 126: 2135-2140.

HU Y, DUTZ JP, MACCALMAN CD, YONG P, TAN R, and VON DADELSZEN P (2006). Decidual NK cells alter in vitro first trimester extravillous cytotrophoblast migration: a role for IFN-gamma. J Immunol 177:8522-8530.

HUGHES M, DOBRIC N, SCOTT IC, SU L, STAROVIC M, ST-PIERRE B, EGAN SE, KINGDOM JC, and CROSS JC (2004). The Hand1, Stra13 and Gcm 1 transcription factors override FGF signaling to promote terminal differentiation of trophoblast stem cells. Dev Biol 271: 26-37.

HUNKAPILLER NM and FISHER SJ (2008). Placental remodeling of the uterine vasculature. Methods Enzymol 445: 281-302.

HUNKAPILLER NM, GASPEROWICZ M, KAPIDZIC M, PLAKS V, MALTEPE E, KITAJEWSKI J, CROSS JC, and FISHER SJ (2011). A role for Notch signaling in trophoblast endovascular invasion and in the pathogenesis of pre-eclampsia. Development 138: 2987-2998.

HUNT JS, MILLER L, VASSMERD, and CROYBA (1997). Expression of the inducible nitric oxide synthase gene in mouse uterine leukocytes and potential relationships with uterine function during pregnancy. Biol Reprod 57: 827-836.

JACOB HJ, LAZAR J, DWINELL MR, MORENO C, and GEURTS AM (2010). Gene targeting in the rat: advances and opportunities. Trends Genet 26: 510-518. 
JANATPOUR MJ, MCMASTER MT, GENBACEV O, ZHOU Y, DONG J, CROSS JC, ISRAEL MA, and FISHER SJ (2000). Id-2 regulates critical aspects of human cytotrophoblast differentiation, invasion and migration. Development 127:549-558.

JANATPOUR MJ, UTSET MF, CROSS JC, ROSSANT J, DONG J, ISRAEL MA, and FISHER SJ (1999). A repertoire of differentially expressed transcription factors that offers insight into mechanisms of human cytotrophoblast differentiation. Dev Genet 25: 146-157.

JAUNIAUX E, WATSON A, and BURTON G (2001). Evaluation of respiratory gases and acid-base gradients in human fetal fluids and uteroplacental tissue between 7 and 16 weeks' gestation. Am J Obstet Gynecol 184: 998-1003.

KADYROV M, SCHMITZ C, BLACK S, KAUFMANN P, and HUPPERTZ B (2003). Pre-eclampsia and maternal anaemia display reduced apoptosis and opposite invasive phenotypes of extravillous trophoblast. Placenta 24: 540-548.

KAMEI T, HAMLIN GP, CHAPMAN BM, BURKHARDT AL, BOLEN JB, and SOARES MJ (1997). Signaling pathways controlling trophoblast cell differentiation: Src family protein tyrosine kinases in the rat. Biol Reprod 57: 1202-1311.

KAMEI T, JONES SR, CHAPMAN BM, MCGONIGLE K, DAI G, and SOARES MJ (2002). Activation and involvement of the phosphatidylinositol 3-kinase/ akt-signaling pathway in the endocrine differentiation of trophoblast cells. $\mathrm{Mol}$ Endocrinol 16: 1469-1481.

KANASAKI K, PALMSTEN K, SUGIMOTO H, AHMAD S, HAMANO Y, XIE L, PARRY $S$, AUGUSTIN HG, GATTONE VH, FOLKMAN J, STRAUSS JF, and KALLURI R (2008). Deficiency in catechol-O-methyltransferase and 2-methoxyoestradiol is associated with pre-eclampsia. Nature 453: 1117-1121.

KAUFMANN P, BLACK S, and HUPPERTZ B (2003). Endovascular trophoblast invasion: implications for the pathogenesis of intrauterine growth retardation and preeclampsia. Biol Reprod 69: 1-7.

KENT LN, KONNOT, and SOARES MJ (2010). Phosphatidylinositol 3-kinase modulation of trophoblast cell differentiation. BMC Dev Biol 10: 97.

KENT LN, RUMI MAK, KUBOTA K, LEE D-S, and SOARES MJ (2011). FOSL1 is integral to establishing the maternal-fetal interface. Mol Cell Biol31: 4801-4813.

KERAMARI M, RAZAVI J, INGMAN KA, PATSCH C, EDENHOFER F, WARD CM, and KIMBER SJ (2010). Sox2 is essential for formation of trophectoderm in the preimplantation embryo. PLoS One 5: e13952.

KESKIN DB, ALLAN DS, RYBALOV B, ANDZELM MM, STERN JN, KOPCOW HD, KOOPMAN LA, and STROMINGER JL (2007). TGFbeta promotes conversion of CD16+ peripheral blood NK cells into CD16- NK cells with similarities to decidual NK cells. Proc Natl Acad Sci USA 104: 3378-3383.

KIDDER BL and PALMER S (2010). Examination of transcriptional networks reveals an important role for TCFAP2C, SMARCA4, and EOMES in trophoblast stem cell maintenance. Genome Res 20: 458-472.

KIECKBUSCHJ, GAYNORLM, MOFFETTA, and COLUCCIF (2014). MHC-dependent inhibition of uterine NK cells impedes fetal growth and decidual vascular remodeling. Nat Commun 5: 3359.

KNÖFLERM (2010). Critical growth factors and signaling pathways controlling human trophoblast invasion. Int J Dev Biol 54: 269-280.

KONNO T, GRAHAM AR, REMPELLA, HO-CHEN JK, ALAM SMK, BU P, RUMI MAK, and SOARES MJ (2010). Subfertility linked to combined luteal insufficiency and uterine progesterone resistance. Endocrinology 151: 4537-4550.

KONNO T, REMPEL LA, ARROYO JA, and SOARES MJ (2007). Pregnancy in the Brown Norway rat: a model for investigating the genetics of placentation. Biol Reprod 76: 709-718.

KONNO T, REMPEL LA, RUMI MAK, GRAHAM AR, ASANOMAK, RENAUD SJ, and SOARES MJ (2011). Chromosome-substituted rat strains provide insights into the genetics of placentation. Physiol Genomics 43: 930-941.

KOOPMAN LA, KOPCOW HD, RYBALOV B, BOYSON JE, ORANGE JS, SCHATZ F, MASCH R, LOCKWOOD CJ, SCHACHTERAD, PARK PJ, and STROMINGER $\mathrm{JL}$ (2003). Human decidual natural killer cells are a unique NK cell subset with immunomodulatory potential. J Exp Med 198: 1201-1212.

KOPCOW HD and KARUMANCHI SA (2007). Angiogenic factors and natural killer (NK) cells in the pathogenesis of preeclampsia. J Reprod Immunol 76: 23-29.

KOZAK KR, ABBOTT B, and HANKINSON O (1997). ARNT-deficient mice and placental differentiation. Dev Biol 191: 297-305.

KUBACZKA C, SENNER C, ARAÚZO-BRAVO MJ, SHARMA N, KUCKENBERG P, BECKERA, ZIMMERA, BRÜSTLE O, PEITZM, HEMBERGERM, and SCHORLE $H$ (2014). Derivation and maintenance of murine trophoblast stem cells under defined conditions. Stem Cell Reports 2: 232-242.

KUCKENBERG P, BUHLS, WOYNECKIT, VANFÜRDENB, TOLKUNOVAE, SEIFFE F, MOSER M, TOMILIN A, WINTERHAGER E, and SCHORLE H (2010). The transcription factor TCFAP2C/AP-2gamma cooperates with CDX2 to maintain trophectoderm formation. $\mathrm{Mol}$ Cell Biol 30: 3310-3320.

LAIZ, KALKUNTES, and SHARMAS (2011). Acritical role of interleukin-10 in modulating hypoxia-induced preeclampsia-like disease in mice. Hypertension 57: 505-514.

LASH GE, OTUN HA, INNES BA, KIRKLEY M, DE OLIVEIRA L, SEARLE RF, ROBSON SC, and BULMER JN (2006a). Interferon-gamma inhibits extravillous trophoblast cell invasion by a mechanism that involves both changes in apoptosis and protease levels. FASEB J 20: 2512-2518.

LASH GE, OTUN HA, INNES BA, PERCIVAL K, SEARLE RF, ROBSON SC, and BULMER JN (2010). Regulation of extravillous trophoblast invasion by uterine natural killer cells is dependent on gestational age. Hum Reprod 25: 1137-1145.

LASH GE, SCHIESSLB, KIRKLEYM, INNESBA, COOPERA, SEARLERF, ROBSON, and BULMER JN (2006b). Expression of angiogenic growth factors by uterine natural killer cells during early pregnancy. J Leukocyte Biol 80: 1-9.

LATOS PA and HEMBERGER M (2014). The transcriptional and signaling networks of mouse trophoblast stem cells. Placenta 35 Suppl A:S81-S85.

LEE SB, WONG AP, KANASAKI K, XU Y, SHENOY VK, MCELRATH TF, WHITESIDES GM, and KALLURI R (2010). Preeclampsia: 2-methoxyestradiol induces cytotrophoblast invasion and vascular development specifically under hypoxic conditions. Am J Pathol 176: 710-720.

LEONARD S, LIMA PD, CROY BA, and MURRANT CL (2013). Gestational modification of murine spiral arteries does not reduce their drug-induced vasoconstrictive responses in vivo. Biol Reprod 89: 139.

LI M, SCHWERBROCK NM, LENHART PM, FRITZ-SIX KL, KADMIEL M, CHRISTINE KS, KRAUS DM, ESPENSCHIED ST, WILLCOCKSON HH, MACK CP, and CARON KM (2013). Fetal-derived adrenomedullin mediates the innate immune milieu of the placenta. J Clin Invest 123: 2408-2420.

LI XF, CHARNOCK-JONES DS, ZHANG E, HIBY S, MALIK S, DAY K, LICENCE D, BOWEN JM, GARDNER L, KING A, LOKE YW, and SMITH SK (2001). Angiogenic growth factor mRNAs in uterine natural killer cells. J Clin Endocrinol Metab 86: 1823-1834.

LI Y, MORETTO-ZITA M, SONCIN F, WAKELAND A, WOLFE L, LEON-GARCIA S, PANDIAN R, PIZZO D, CUI L, NAZOR K, LORING JF, CRUM CP, LAURENT LC, and PARAST MM (2013). BMP4-directed trophoblast differentiation of human embryonic stem cells is mediated through a $\Delta N p 63+$ cytotrophoblast stem cell state. Development 140: 3965-3976.

MALTEPE E, BAKARDJIEV Al, and FISHER SJ (2010). The placenta: transcriptional, epigenetic, and physiological integration during development. J Clin Invest 120: 1016-1025.

MALTEPE E, KRAMPITZ GW, OKAZAKI KM, RED-HORSE K, MAK W, SIMON MC and FISHER SJ (2005). Hypoxia-inducible factor-dependent histone deacetylase activity determines stem cell fate in the placenta. Development 132: 3393-3403.

MOSSMAN HW (1987). Vertebrates Fetal Membranes. Rutgers University Press, New Brunswick, NJ.

MUROHASHI M, NAKAMURA T, TANAKAS, ICHISE T, YOSHIDAN, YAMAMOTO T, SHIBUYA M, SCHLESSINGER J, and GOTOH N (2010). An FGF4-FRS2alphaCdx2 axis in trophoblast stem cells induces Bmp4 to regulate proper growth of early mouse embryos. Stem Cells 28: 113-121.

NAGASHIMA T, LI Q, CLEMENTI C, LYDON JP, DEMAYO FJ, and MATZUK MM (2013). BMPR2 is required for postimplantation uterine function and pregnancy maintenance. J Clin Invest 123: 2539-2550.

NAKAYAMA H, LIU Y, STIFANI S, and CROSS JC (1997). Developmental restriction of Mash-2 expression in trophoblast correlates with potential activation of the Notch-2 pathway. Dev Genet 21: 21-30.

NG RK, DEANW, DAWSON C, LUCIFERO D, MADEJAZ, REIKW, and HEMBERGER M 2008 Epigenetic restriction of embryonic cell lineage fate by methylation of Elf5. Nat Cell Biol 10: 1280-1290.

NISHIOKA N, INOUE K, ADACHI K, KIYONARI H, OTA M, RALSTON A, YABUTA N, HIRAHARA S, STEPHENSON RO, OGONUKI N, MAKITA R, KURIHARA H, MORIN-KENSICKI EM, NOJIMA H, ROSSANT J, NAKAO K, NIWA H, and SASAKI H (2009). The Hippo signaling pathway components Lats and Yap pattern Tead4 activity to distinguish mouse trophectoderm from inner cell mass. Dev Cell 16: 398-410. 
NIWA H, TOYOOKA Y, SHIMOSATO D, STRUMPF D, TAKAHASHI K, YAGI R, and ROSSANT J (2005). Interaction between Oct3/4 and Cdx2 determines trophectoderm differentiation. Cell 123: 917-929.

OCKLEFORD CD (2010). The allo-epi-endothelial lining of the intervillous space. Placenta 31: 1035-1042.

OSOL G and MANDALA M (2009). Maternal uterine vascular remodeling during pregnancy. Physiology (Bethesda) 24: 58-71.

OSOL G and MOORE LG (2014). Maternal uterine vascular remodeling during pregnancy. Microcirculation 21: 38-47.

PARHAM P and MOFFETT A (2013). Variable NK cell receptors and their MHC class I ligands in immunity, reproduction and human evolution. Nat Rev Immunol 13: 133-144.

PAUL S and KNOTT JG (2014). Epigenetic control of cell fate in mouse blastocysts: The role of covalent histone modifications and chromatin remodeling. Mol Reprod Dev 81: 171-182.

PFEFFER PL and PEARTON DJ (2012). Trophoblast development. Reproduction 143: 231-246.

PIJNENBORG R and VERCRUYSSE L (2010). Animal models of deep trophoblast invasion. In Placental bed disorders: basic science and its translation to obstetrics (Eds R Pijnenborg, I Brosens, R Romero). Cambridge University Press, Cambridge, pp. 127-139.

PIJNENBORG R, VERCRUYSSE L, and HANSSENS M (2006). The uterine spira arteries in human pregnancy: facts and controversies. Placenta 27: 939-958.

POLLHEIMER J, HASLINGER P, FOCK V, PRAST J, SALEH L, BIADASIEWICZ K, JETNE-EDELMANN R, HARALDSEN G, HAIDER S, HIRTENLEHNER-FERBER $\mathrm{K}$, and KNÖFLER M (2011). Endostatin suppresses IGF-II-mediated signaling and invasion of human extravillous trophoblasts. Endocrinology 152: 4431-4442.

POLLHEIMER J and KNÖFLERM (2005). Signalling pathways regulating the invasive differentiation of human trophoblasts: a review. Placenta 26 Suppl A: S21-S30.

PRAST J, SALEH L, HUSSLEIN H, SONDEREGGER S, HELMER H, and KNÖFLER $M$ (2008). Human chorionic gonadotropin stimulates trophoblast invasion through extracellularly regulated kinase and AKT signaling. Endocrinology 149: 979-987.

QIU Q, YANG M, TSANG BK, and GRUSLIN A (2004). EGF-induced trophoblast secretion of MMP-9 and TIMP-1 involves activation of both PI3K and MAPK signalling pathways. Reproduction 128: 355-363.

RAHMAN MA, LI M, LI P, WANG H, DEY SK, and DAS SK (2006). Hoxa-10 deficiency alters region-specific gene expression and perturbs differentiation of natural killer cells during decidualization. Dev Biol 290: 105-117.

RAI A and CROSS JC (2014). Development of the hemochorial maternal vascular spaces in the placenta through endothelial and vasculogenic mimicry. Dev Biol 387: $131-141$.

RALSTON A, COX BJ, NISHIOKA N, SASAKI H, CHEAE, RUGG-GUNN P, GUO G, ROBSON P, DRAPER JS, and ROSSANT J (2010). Gata3 regulates trophoblast development downstream of Tead4 and in parallel to Cdx2. Development 137: 395-3403.

RAY S, DUTTA D, RUMI MA, KENT LN, SOARES MJ, and PAUL S (2009). Contextdependent function of regulatory elements and a switch in chromatin occupancy between GATA3 and GATA2 regulate Gata2 transcription during trophoblast differentiation. J Biol Chem 284: 4978-4988.

RENAUD SJ, COTECHINI T, QUIRT JS, MACDONALD-GOODFELLOW SK, OTHMAN M, and GRAHAM CH (2011). Spontaneous pregnancy loss mediated by abnormal maternal inflammation in rats is linked to deficient uteroplacental perfusion. J Immunol 186: 1799-1808.

RENAUD SJ, KUBOTA K, RUMI MAK, and SOARES MJ (2014). The FOS transcription factor family differentially controls trophoblast migration and invasion. $J$ Biol Chem 289: 5025-5039.

RIELLAND M, HUE I, RENARD JP, and JOUNEAU A (2008). Trophoblast stem cell derivation, cross-species comparison and use of nuclear transfer: new tools to study trophoblast growth and differentiation. Dev Biol 322: 1-10.

ROBERTS RM and FISHERSJ (2011) Trophoblast stem cells. Biol Reprod84:412-421.

ROBSONA, HARRIS LK, INNES BA, LASH GE, ALJUNAIDY MM, APLIN JD, BAKER PN, ROBSON SC, and BULMER JN (2012). Uterine natural killer cells initiate spiral artery remodeling in human pregnancy. FASEB J 26: 4876-4885.

ROSARIO GX, KONNO T, and SOARES MJ (2008). Maternal hypoxia-activated endovascular trophoblast cell invasion. Dev Biol 314: 362- 375.
RUGG-GUNN PJ, COX BJ, RALSTON A, and ROSSANT J (2010). Distinct modifications in stem cell lines and tissue lineages from the early mouse embryo. Proc Natl Acad Sci USA 107: 10783-10790.

RUGG-GUNN PJ (2012). Epigenetic features of the mouse trophoblast. Reprod BioMed Online 25: 21-30.

RUMI MAK, DHAKAL P, KUBOTA K, CHAKRABORTY D, LEI T, LARSON MA, WOLFE MW, ROBY, KF, VIVIAN JL, and SOARES MJ (2013). Generation of Esr1 knockout rats using zinc finger nuclease-mediated genome editing. Endocrinology 155: 1991-1999.

SAHA B, HOME P, RAY S, LARSON M, PAUL A, RAJENDRAN G, BEHR B, and PAUL $S$ (2013). EED and KDM6B coordinate the first mammalian cell lineage commitment to ensure embryo implantation. $\mathrm{Mol}$ Cell Biol 33:2691-2705.

SANTOS J, PEREIRA CF, DI-GREGORIO A, SPRUCE T, ALDER O, RODRIQUEZ T, AZUARA V, MERKENSCHLAGER M and FISHER AG (2010). Differences in the epigenetic and reprogramming properties of pluripotent and extra-embryonic stem cells implicate chromatin remodelling as an important early event in the developing mouse embryo. Epigenetics Chromatin 3: 1.

SCHÄFFER L, VOGEL J, BREYMANN C, GASSMANN M, and MARTI HH (2006). Preserved placental oxygenation and development during severe systemic hypoxia. Am J Physiol Regul Integr Comp Physiol 290: R844-R851.

SCHORPP-KISTNER M, WANG ZQ, ANGEL P, and WAGNER EF (1999). JunB is essential for mammalian placentation. EMBO J 18: 934-948.

SCHREIBER M, WANG ZQ, JOCHUM W, FETKA I, ELLIOTT C, and WAGNER EF (2000). Placental vascularisation requires the AP-1 component fra1. Development 127: 4937-4948

SEMENZA GL (2010). Oxygen homeostasis. Wiley Interdiscip Rev Syst Biol Med 2: 336-361.

SHENOY V, KANASAKI K, and KALLURI R (2010). Pre-eclampsia: connecting angiogenic and metabolic pathways. Trends Endocrinol Metab 21: 529-536.

SMITH SD, DUNK CE, APLIN JD, HARRIS LK, and JONES RL (2009). Evidence for immune cell involvement in decidual spiral arteriole remodeling in early human pregnancy. Am J Pathol 174: 1959-1971.

SONDEREGGER S, HASLINGER P, SABRI A, LEISSER C, OTTEN JV, FIALA C and KNÖFLER M (2010). Wingless (Wnt)-3A induces trophoblast migration and matrix metalloproteinase-2 secretion through canonical Wnt signaling and protein kinase B/AKT activation. Endocrinology 151: 211-220.

SOARES MJ, CHAKRABORTY D, RUMI MAK, KONNO T, and RENAUD SJ (2012). Rat placentation: an experimental model for investigating the hemochorial maternal-fetal interface. Placenta 33: 233-243.

STRASZEWSKI-CHAVEZ SL, ABRAHAMS VM, ALVERO AB, ALDO PB, MA Y, GULLER S, ROMERO R, and MOR G (2009). The isolation and characterization of a novel telomerase immortalized first trimester trophoblast cell line, Swan 71 Placenta 30: 939-948.

TACHE V, CIRIC A, MORETTO-ZITAM, LI Y, PENG J, MALTEPE E, MILSTONE DS, and PARAST MM (2013). Hypoxia and trophoblast differentiation: a key role for PPAR . Stem Cells Dev 22:2815-2824.

TAKAO T, ASANOMA K, KATO K, FUKUSHIMA K, TSUNEMATSU R, HIRAKAWA T, MATSUMURA S, SEKI H, TAKEDA S, and WAKE N (2011). Isolation and characterization of human trophoblast side-population (SP) cells in primary villous cytotrophoblasts and HTR-8/SVneo cell line. PLoS One 6: e21990.

TAKEDA K, HO VC, TAKEDA H, DUAN LJ, NAGY A, and FONG GH (2006). Placental but not heart defects are associated with elevated hypoxia-inducible factor alpha levels in mice lacking prolyl hydroxylase domain protein 2. Mol Cell Biol 26: 8336-8346.

TANAKA S, KUNATH T, HADJANTONAKIS AK, NAGY A, and ROSSANT J (1998). Promotion of trophoblast stem cell proliferation by FGF4. Science 282: 2072-2075.

TEESALU T, BLASI F, and TALARICO D (1998). Expression and function of the urokinase type plasminogen activator during mouse hemochorial placental development. Dev Dyn 213: 27-38.

TOLKUNOVA E, CAVALERI F, ECKARDT S, REINBOLD R, CHRISTENSON LK, SCHÖLER HR, and TOMILINA (2006). The caudal-related protein Cdx2 promotes trophoblast differentiation of mouse embryonic stem cells. Stem Cells 24: 139-144.

TOMLINSON TM, GARBOW JR, ANDERSON JR, ENGELBACH JA, NELSON DM, and SADOVSKY Y (2010). Magnetic resonance imaging of hypoxic injury to the murine placenta. Am J Physiol Regul Integr Comp Physiol 298: R312-R319.

TREMBLAY GB, KUNATHT, BERGERON D, LAPOINTE L, CHAMPIGNY C, BADER 
JA, ROSSANT J, and GIGUÈRE V (2001). Diethylstilbestrol regulates trophoblast stem cell differentiation as a ligand of orphan nuclear receptor ERR beta. Genes Dev 15: 833-838.

TUULI MG, LONGTINE MS, and NELSON DM (2011). Oxygen and trophoblast biology - a source of controversy. Placenta 32 Suppl 2: S109-S118.

UENO M, LEE LK, CHHABRAA, KIM YJ, SASIDHARAN R, VAN HANDEL B, WANG Y, KAMATA M, KAMRAN P, SERETI KI, ARDEHALI R, JIANG M, and MIKKOLA HK (2013). c-Met-dependent multipotent labyrinth trophoblast progenitors establish placental exchange interface. Dev Cell 27: 373-386.

VAN DIJK M, MULDERS J, POUTSMAA, KÖNST AA, LACHMEIJER AM, DEKKER GA, BLANKENSTEIN MA, and OUDEJANS CB (2005). Maternal segregation of the Dutch preeclampsia locus at $10 \mathrm{q} 22$ with a new member of the winged helix gene family. Nat Genet 37: 514-519.

VAN DIJK M and OUDEJANS C (2013). (Epi)genetics of pregnancy-associated diseases. Front Genet 4: 180.

VANDIJK M, THULLURU HK, MULDERS J, MICHELOJ, POUTSMAA, WINDHORST S, KLEIVERDA G, SIE D, LACHMEIJERAM, and OUDEJANS CB (2012). HELLP babies link a novel lincRNA to the trophoblast cell cycle. J Clin Invest 122: 4003-4011.

VANDIJKM, VANBEZUJ, VANABELD, DUNK C, BLANKENSTEIN MA, OUDEJANS CB, and LYE SJ (2010). The STOX1 genotype associated with pre-eclampsia leads to a reduction of trophoblast invasion by alpha-T-catenin upregulation. Hum Mol Genet 19: 2658-2667.

VANDIJKM, THULLURU HK, MULDERS J, MICHELOJ, POUTSMAA, WINDHORST S, KLEIVERDA G, SIE D, LACHMEIJERAM, and OUDEJANS CB (2012). HELLP babies link a novel lincRNA to the trophoblast cell cycle. J Clin Invest 122: 4003-4011.

VERCRUYSSE L, CALUWAERTS S, LUYTEN C, and PIJNENBORG R (2006). Interstitial trophoblast invasion in the decidua and mesometrial triangle during the last third of pregnancy in the rat. Placenta 27: 22-33.

VIĆOVAC LandAPLINJD (1996). Epithelial-mesenchymal transition during trophoblast differentiation. Acta Anat (Basel) 156: 202-216.

WALLACE AE, FRASER R, and CARTWRIGHT JE (2012). Extravillous trophoblast and decidual natural killer cells: a remodelling partnership. Hum Reprod Update 18:458-471.

WALLACE AE, HOST AJ, WHITLEY GS, and CARTWRIGHT JE (2013). Decidual natural killer cell interactions with trophoblasts are impaired in pregnancies at increased risk of preeclampsia. Am J Pathol 183:1853-1861.

WANG $\mathrm{C}$, TANAKA T, NAKAMURA $\mathrm{H}$, UMESAKI N, HIRAI K, ISHIKO O, OGITA $S$, and KANEDA K (2003). Granulated metrial gland cells in the murine uterus: localization, kinetics, and the functional role in angiogenesis during pregnancy. Micros Res Tech 60: 420-429.

WANG C, UMESAKI N, NAKAMURA H, TANAKA T, NAKATANI K, SAKAGUCHI I, OGITA S, and KANEDA K (2000). Expression of vascular endothelial growth factor by granulated metrial gland cells in pregnant murine uteri. Cell Tissue Res 300: 285-293.

WANG K, SENGUPTA S, MAGNANI L, WILSON CA, HENRY RW, and KNOTT JG (2010). Brg1 is required for Cdx2-mediated repression of Oct4 expression in mouse blastocysts. PLoS One 5: e10622.

WEN F, TYNAN JA, CECENA G, WILLIAMS R, MÚNERA J, MAVROTHALASSITIS G, and OSHIMA RG 2007 Ets2 is required for trophoblast stem cell self-renewal. Dev Biol 312: 284-299.

WHITLEY GS (2006). Production of human trophoblast cell lines. Methods Mol Med 121: $219-228$

WIEMERS DO, AIN R, OHBOSHI S, and SOARES MJ (2003). Migratory trophoblast cells express a newly identified member of the prolactin gene family. J Endocrinol 179: 335-346.

WITHINGTON SL, SCOTT AN, SAUNDERS DN, LOPES FLORO K, PREIS J, MICHALICEK J, MACLEAN K, SPARROW DB, MARTINEZ BARBERA JP, and DUNWOODIE SL (2006). Loss of Cited2 affects trophoblast formation and vascularization of the mouse placenta. Dev Biol 294: 67-82.

WOODING FBP, BURTON GJ (2008). Comparative Placentation - Structures, Functions, and Evolution. Springer-Verlag, Berlin, Heidelberg.

XIONG S, SHARKEY AM, KENNEDY PR, GARDNER L, FARRELL LE, CHAZARA O, BAUER J, HIBY SE, COLUCCI F, and MOFFETT A (2013). Maternal uterine NK cell-activating receptor KIR2DS1 enhances placentation. J Clin Invest 123 4264-4272.

XU RH, CHEN X, LI DS, LI R, ADDICKS GC, GLENNON C, ZWAKA TP, and THOMSON JA (2002). BMP4 initiates human embryonic stem cell differentiation to trophoblast. Nat Biotechnol 20: 1261-1264.

YEAP L-S, HAYASHI K, and SURANI MA (2009). ERG-associated protein with SET domain (ESET)-Oct 4 interaction regulates pluripotency and represses the trophectoderm lineage. Epigenetics Chromatin 2: 12

YUAN P, HAN J, GUO G, ORLOV YL, HUSS M, LOH Y-H, YAW L-P, ROBSON P, LIM B, and NG H-H (2009). Eset partners with Oct4 to restrict extraembryonic trophoblast lineage potential in embryonic stem cells. Genes Dev23: 2507-2520.

YUEN RKC, CHEN B, BLAIR JD, ROBINSON WP, and NELSON DM (2013). Hypoxia alters the epigenetic profile in cultured human placental trophoblasts. Epigenetics 8: 192-202.

ZAMUDIO S (2003). The placenta at high altitude. High Alt Med Biol 4: 171-191.

ZHANG J, CHEN Z, SMITH GN, and CROY BA (2011). Natural killer cell-triggered vascular transformation: maternal care before birth? Cell Mol Immunol 8: 1-11.

ZHOU S, XIE Y, PUSCHECK EE, and RAPPOLEE DA (2011). Oxygen levels that optimize TSC culture are identified by maximizing growth rates and minimizing stress. Placenta 32: 475-481.

ZHOU Y, CHIU K, BRESCIA RJ, COMBS A, KATZ MA, KITZMILLER JL, HEILBRON DC, and FISHER SJ (1993). Increased depth of trophoblast invasion after chronic constriction of the lower aorta in rhesus monkeys. Am J Obstet Gynecol 169: 224-229.

ZHU D, HÖLZ S, METZGER E, PAVLOVIC M, JANDAUSCH A, JILG C, GALGOCZY P, HERZ C, MOSER M, METZGER D, GÜNTHER T, ARNOLD SJ, and SCHÜLE $R$ (2014). Lysine-specific demethylase 1 regulates differentiation onset and migration of trophoblast stem cells. Nat Commun 5: 3174. 


\section{Further Related Reading, published previously in the Int. J. Dev. Biol.}

Life-giving caspases: revealing new roles during mouse embryo preimplantation development

Dolores Busso, Calixto Dominguez, Tomas Perez-Acle and Ricardo D. Moreno

Int. J. Dev. Biol. (2010) 54: 857-865

On the role of placental major histocompatibility complex and decidual leukocytes in implantation and pregnancy success using non-human primate models

Thaddeus G. Golos, Gennadiy I. Bondarenko, Svetlana V. Dambaeva, Edith E. Breburda, and Maureen Durning

Int. J. Dev. Biol. (2010) 54: 431-443

Local regulation of implantation at the human fetal-maternal interface

Evdokia Dimitriadis, Guiying Nie, Natalie J. Hannan, Premila Paiva and Lois A. Salamonsen

Int. J. Dev. Biol. (2010) 54: 313-322

Complement component $\mathbf{C} 3$ functions as an embryotrophic factor in early postimplantation rat embryos

Makoto Usami, Katsuyoshi Mitsunaga, Atsuko Miyajima, Momoko Sunouchi and Osamu Doi

Int. J. Dev. Biol. (2010) 54: 1277-1285

Immune cells in the placental bed

Judith N. Bulmer, Paula J. Williams and Gendie E. Lash

Int. J. Dev. Biol. (2010) 54: 281-294

Placentation in mammals once grouped as insectivores

Anthony M. Carter and Allen C. Enders

Int. J. Dev. Biol. (2010) 54: 483-493

A simple in vivo approach to investigate invasive trophoblast cells Juan A. Arroyo, Toshihiro Konno, Darya C. Khalili and Michael J. Soares Int. J. Dev. Biol. (2005) 49: 977-980

Vascular development: from precursor cells to branched arterial and venous networks Anne Eichmann, Li Yuan, Delphine Moyon, Ferdinand leNoble, Luc Pardanaud and Christiane Bréant

Int. J. Dev. Biol. (2005) 49: 259-267

5 yr ISI Impact Factor $(2011)=2.959$
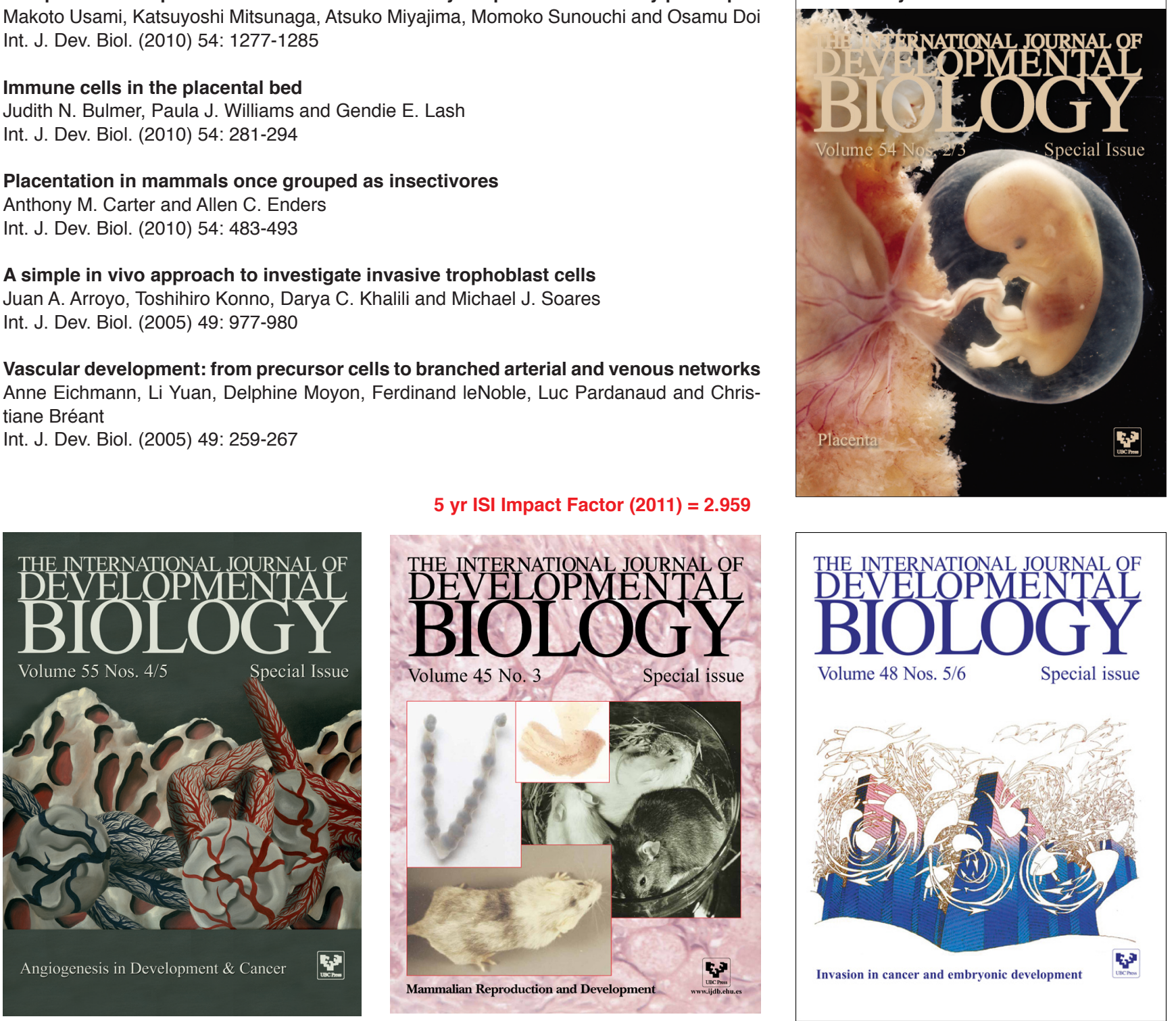

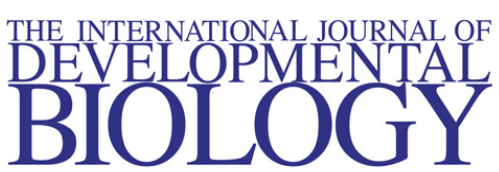

Volume 48 Nos. 5/6

Special issue

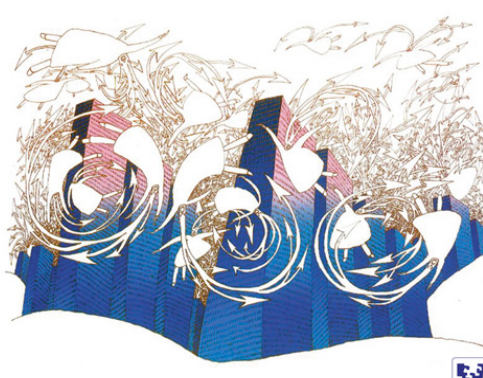

Invasion in cancer and embryonic development 